\title{
Explanation of the Damage to the Royal Family's Cemetery in Historic Cairo and Examination of the Building Materials
}

\author{
Ahmed Elyamani1 ${ }^{*}$, Nabil A. Abd El-Tawab Bader², Mahmoud Algohary', Ragab Abou El Hassan ${ }^{3}$ \\ ${ }^{1}$ Department of Archaeological Conservation, Faculty of Archaeology, Cairo University, Cairo, Egypt \\ ${ }^{2}$ Treatment and Conservation Department, Faculty of Archaeology, Zagazig University, Zagazig, Egypt \\ ${ }^{3}$ Restoration and Conservation of Antiquities Department, Faculty of Archaeology and Tourism Guidance, Misr University for \\ Science and Technology, 6th October City, Egypt \\ Email: ^a_elyamani@cu.edu.eg
}

How to cite this paper: Elyamani, A., Abd El-Tawab Bader, N.A., Algohary, M. and Abou El Hassan, R. (2021) Explanation of the Damage to the Royal Family's Cemetery in Historic Cairo and Examination of the Building Materials. Open Journal of Civil Engineering, 11, 28-59.

https://doi.org/10.4236/ojce.2021.111003

Received: January 24, 2021

Accepted: February 22, 2021

Published: February 25, 2021

Copyright $\odot 2021$ by author(s) and Scientific Research Publishing Inc. This work is licensed under the Creative Commons Attribution International License (CC BY 4.0).

http://creativecommons.org/licenses/by/4.0/

cc) (i) Open Access

\begin{abstract}
The cemetery of the royal family, who ruled Egypt from 1805 to 1952, is one of the masterpieces of the UNESCO World Heritage Site of Historic Cairo. It is a complex building from massive stone masonry walls supporting hemispherical domes and is very rich with the marble decorative elements. Unfortunately, it suffers nowadays from serious cracking due to on-going structural damage. Almost all the structural elements are cracked. Besides, the continuous rise in the groundwater table affects both its structural stability and aesthetics. A detailed inspection was carried out to identify and explain all the manifested damage by the structural elements of the cemetery. The differential settlement damage was found to be very noticeable in the form of many diagonal cracks that are active and threaten the overall stability of the cemetery. The construction history was investigated and found to have a clear effect on the noticed damage. Examination of the construction materials and deterioration products was carried out by inspecting representative samples of the stone, the marble, the mortar, the plaster and the salt. They were examined using different analysis techniques including the Polarized Microscope, the Stereo Microscope, the X-Ray Diffraction (XRD), and the Scanning Electron Microscope (SEM) provided with Energy-Dispersive X-ray spectroscopy (EDX) unit. This examination helped in identifying the type of the used stone, the mortar components, the types of salts affecting the structure, and the deterioration manifested by the marble. It seems that the cemetery needs an urgent conservation project to stop the deterioration and keep it safe for the next generations.
\end{abstract}




\section{Keywords}

Historic Cairo, Cemetery, Differential Settlement, Groundwater, Damage, XRD, SEM-EDX, Examination

\section{Introduction}

Historic Cairo is a UNESCO World Heritage Site since 1979. It was listed because of its richness in valueless Islamic, Coptic and Jewish historic structures dating back to several centuries ago. The authorities in charge of this unique historic site spare no effort to preserve it and keep it safe for the next generations. Nevertheless, the preservation of such a big historic site containing more than 600 historic structures with an area of more than 5 million $\mathrm{m}^{2}$ is a very complex issue. Besides, many authorities are in charge of Historic Cairo including the Ministry of Tourism and Antiquities, the Governorate of Cairo, the Ministry of Housing, among others. The multitude of authorities affects negatively the decisions and actions taken for identifying the site's problems and putting in action proper conservation plans.

Historic Cairo suffers from many problems nowadays. The continuous rise of the groundwater level comes to the fore. The groundwater is probably the major cause of damage to the historic structures in Historic Cairo as mentioned in many previous studies [1] [2] [3] [4] [5]. The reasons for the groundwater level increase include, but are not limited to, the nature of the aquifer of the groundwater in Cairo that is classified as confined to semi-confined that makes the groundwater level increase due to any surface rainfalls or water leakages [6]. In addition, the leakage from the existing water supply and sewage systems and the population growth on unplanned urban expansions are not served with sewage systems [7] [8] [9]. Furthermore, the filling of the historic open water resources during the modernization of Cairo since the first half of the 19th century resulted in an increase in the groundwater level. The water pools of "Birkat al-Azbakkiyya" and "Birkat al-Fil" and the canal of "al-Khalij al-Masri", among others, all were filled [6].

What enlarges the damage to the historic structures in Historic Cairo, under the effect of the groundwater increase is the type of the foundation soil. Many studies were carried out for the characterization of the foundation soil of Historic Cairo [3] [10] [11] [12] [13] [14]. The studies included data on the boreholes carried out to different depths from the natural ground level and the soil geological data for large depths.

It was revealed that the soil layers in the sequence are non-homogeneous fill followed by clayey soil and end with large deposits of sand or rock. Regarding the reason behind the existence of the fill layer, in particular, El-Sohby and Mazen (1988) [14] explained that the human occupation of Historic Cairo along with its history that extended more than a millennium resulted in considerable debris. This was due to the destruction in $905 \mathrm{AD}$ of Al-Qataie city and then the 
burning of Al-Fustat city in $1168 \mathrm{AD}$ that caused a big area of land to be abandoned and with the passing of the time, more accumulation of filling on the ruin turned it to become one connected area of the rubbish heap. Besides, during the reign of Muhammed Ali Pasha and his succors, many lakes, ponds, and swamps were filled and levelled, and then new roads and buildings were built upon. It is well known that non-homogeneous fill has unpredicted behavior when subjected to groundwater that in turn affects the foundations in the form of differential settlements or much worse bearing capacity failure.

In this context, this paper discusses one of the masterpieces of Historic Cairo. It is called the Royal Family's Cemetery built during the 19th and 20th Centuries. It is also known by Hosh al-Basha. Hosh is an Arabic word that means courtyard and is used to mean cemetery. al-Basha is an Ottoman title used for highly ranked men in the state. It was also the title given to the Ottoman governors of Egypt. The Royal Family started with Muhammed Ali Pasha who ruled Egypt from 1805 to 1848.

Hosh al-Basha is a very good example to represent the typical problems suffered by historic structures in Historic Cairo including the groundwater rise, the differential settlement resulting from foundation soil type and affecting the overall stability, and the late preservation plans from the authorities.

The paper presents the construction history and the location of Hosh al-Basha and links both to the observed damage nowadays. In addition, a detailed inspection of all the spaces of the cemetery was carried out to identify the manifested damage and its reasons. Samples were taken from the construction materials including the stone, the marble, the mortar, the plaster, and the deterioration products in the form of salts. Different examination tools were used including the Light and the Polarized Microscopes, the X-Ray Diffraction (XRD), and the Scanning Electron Microscope (SEM) provided with Energy-Dispersive X-ray spectroscopy (EDX) unit. The purpose was to reveal the type and the chemical composition of the different construction materials and to reveal the damage caused by the different damage causes such as groundwater rise.

\section{Location}

Hosh al-Basha is located in the southeast of Historic Cairo near Qubba al-Imam al-Shafi'i in the area called al-Imam al-Shafi'i, Figure 1(a). The two natural pools of Ain Al-Sira and Khayalat Al-Shorta (called also al-Imam al-Shafi'i pool) are found nearby, the former is about $600 \mathrm{~m}$ and the latter is about $3 \mathrm{~km}$ from Hosh al-Basha, Figure 1(b). This in turn has an effect on the observed damage of the structure of Hosh al-Basha due to the rise of the groundwater as will be discussed later. About $80 \mathrm{~m}$ from Hosh al-Basha, the Qubba al-Imam al-Shafi'i exists, Figure 1(c).

\section{Historical Background}

\section{Construction of Hosh al-Basha and the Buried Persons}

Hosh al-Basha is a domed complex (Figure 2); it does not have a foundation text 
for its exact construction dating. However, Abed (1998) [16] managed to reveal the different consequent construction phases by tracking the dates written on the tombstones and other historical resources.

According to [16], the first phase of construction (Phase I) was ended in 1805 before Muhammad Ali Pasha purchased the cemetery. At that time the cemetery consisted of the three rooms from (1) to (3) shown in Figure 3(a). This Figure shows the development in the time of Hosh al-Basha. During this period also, the room (3) in specific was renovated to receive the body of the beloved son of Muhammad Ali Pasha called Ahmed Toson Pasha who died in the war in 1816. The dome of the room (3) is different from the other two domes of the rooms (1) and (2) as will be explained later in the description of the cemetery.
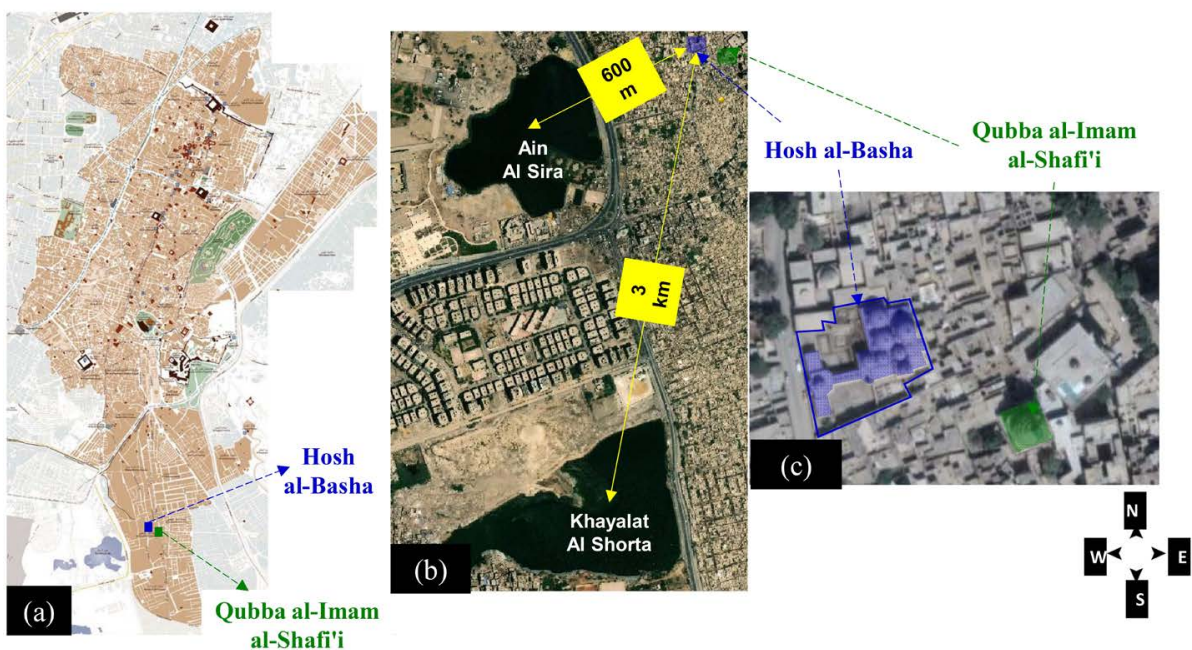

Figure 1. The location of Hosh al-Basha: (a) south east of Historic Cairo (map source [13]), (b) zoom to the location showing near distance to Ain Al Sira and Khaylat Al Shorta pools, (c) the near distance between Hosh al-Basha and Qubba al-Imam al-Shafi'I ( 80 m) ("b" \& "c" adopted from [15]). (explanations by the authors).

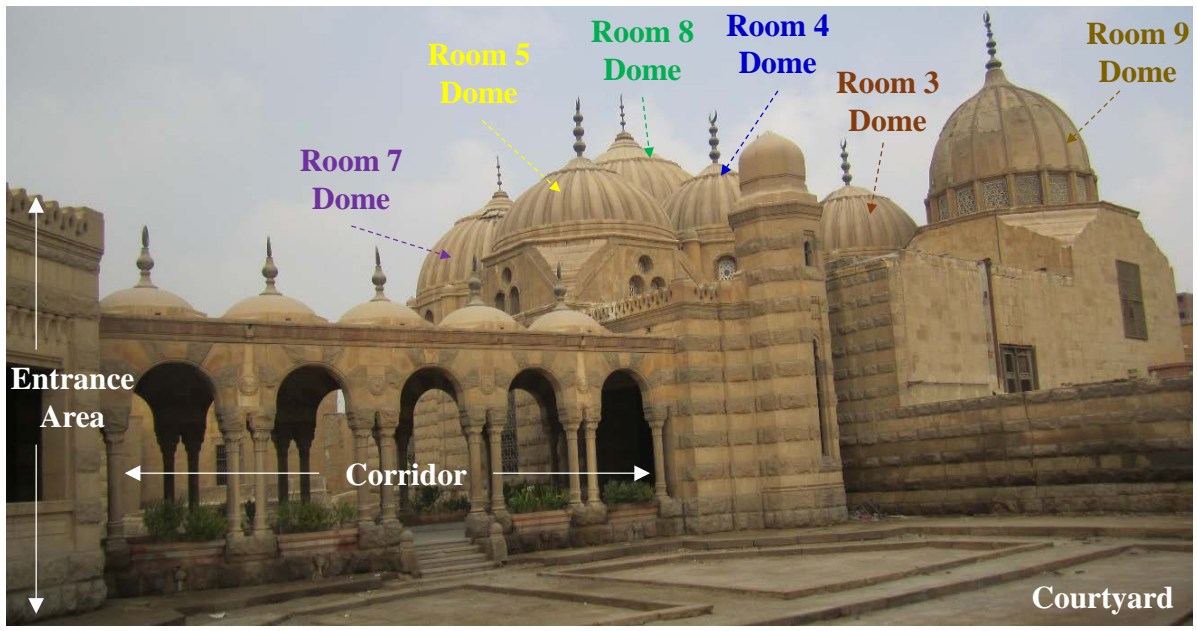

Figure 2. External view of Hosh al-Basha showing a part of the entrance area, the corridor, the courtyard and the rooms' domes. (photo and explanations by the authors). 
Regarding the buried persons within this first phase (1805-1816), 25 of the royal family were buried in this cemetery as indicated in Figure 4. This Figure was created based on the data mentioned in [16]. It shows the death year of the buried person and his/her relation with Muhammad Ali Pasha. As can be noticed the buried persons represented the members of the family of Muhammad Ali Pasha including the sons and daughters, the grandsons and granddaughters, the great grandchild's, the wives, and the relatives from 1st, 2nd, and 3rd degrees and their relatives. Besides, other family members were buried in the cemetery. It should be noticed that in total 74 persons between males, females and children were buried in this cemetery from the year 1805 to the year 1902. Muhammed Ali Pasha died in 1848, as mentioned before, and during his life, 54 from the royal family were buried in this cemetery. Among the buried persons in this period were two sons of Muhammad Ali Pasha (No'man and G'fr) and three daughters (Roqia, Zolikh, and Salma).

The second phase of construction (phase II) included the addition of the two rooms (4) and (5) during the period from 1816 to 1823, Figure 3(b). Ismail Pasha the son of Muhammed Ali Pasha died in the war in Sudan in 1822 was buried in the room (4). In the room (5), Amina Hanem and Roqia Hanem, the wife and the granddaughter of Muhammad Ali Pasha, respectively, were buried.
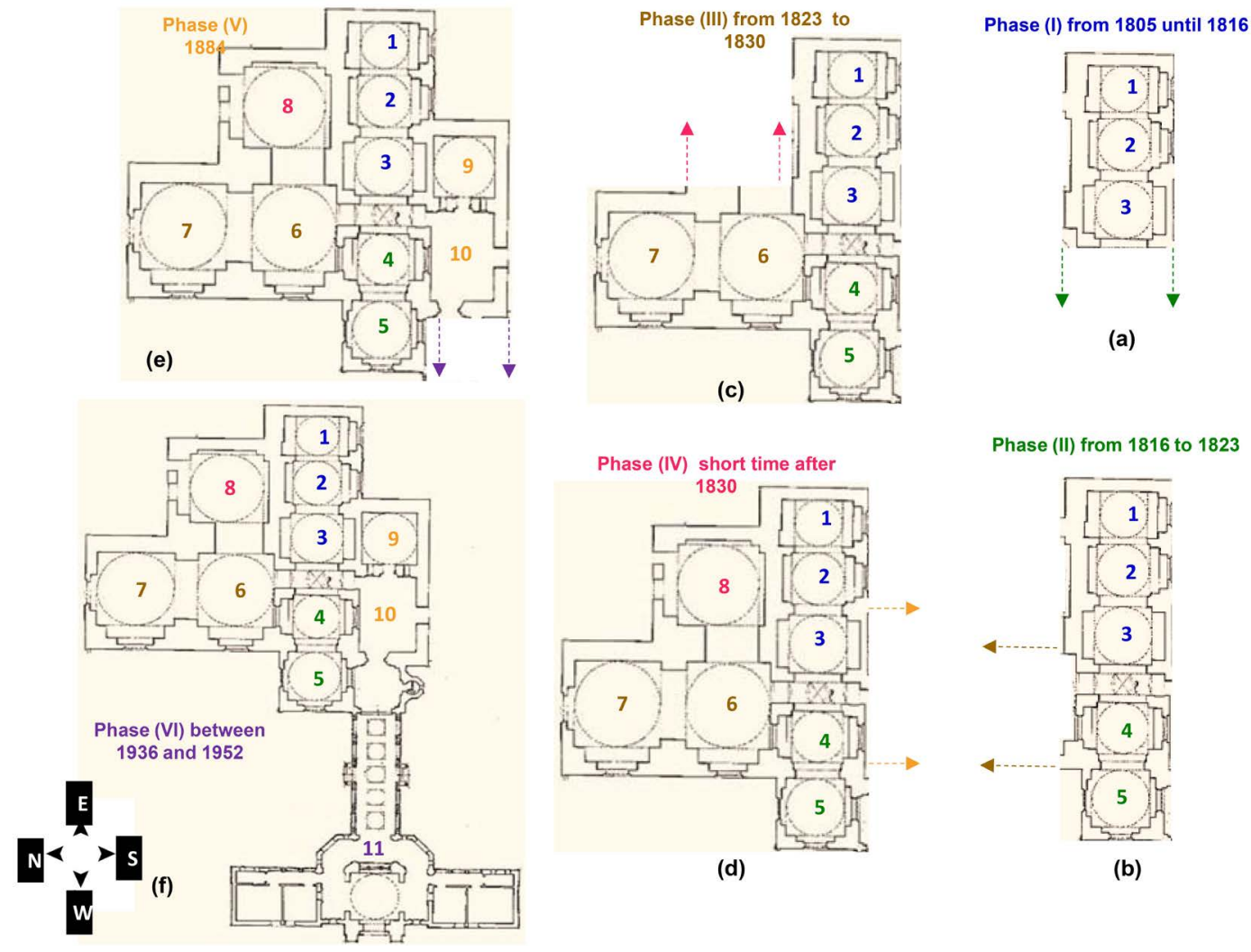

(a)

Phase (II) from 1816 to 1823

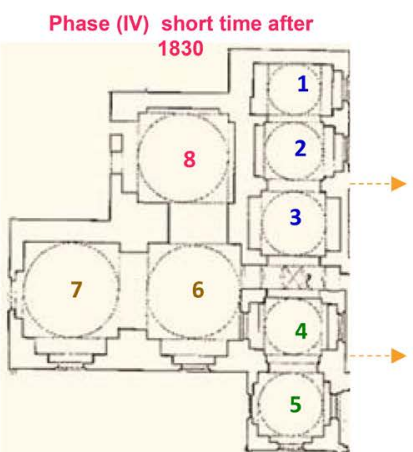

(d)

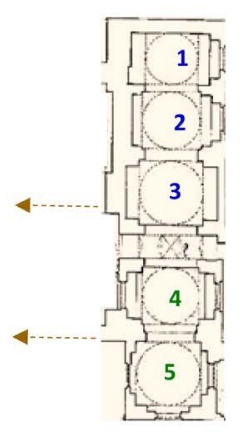

(b)

Figure 3. Historical progress of the construction phases of Hosh al-Basha from (a) Phase I (top right) to (f) Phase VI (bottom left) (arrows show the direction of expansion). (plan source from [17], explanations by the authors). 

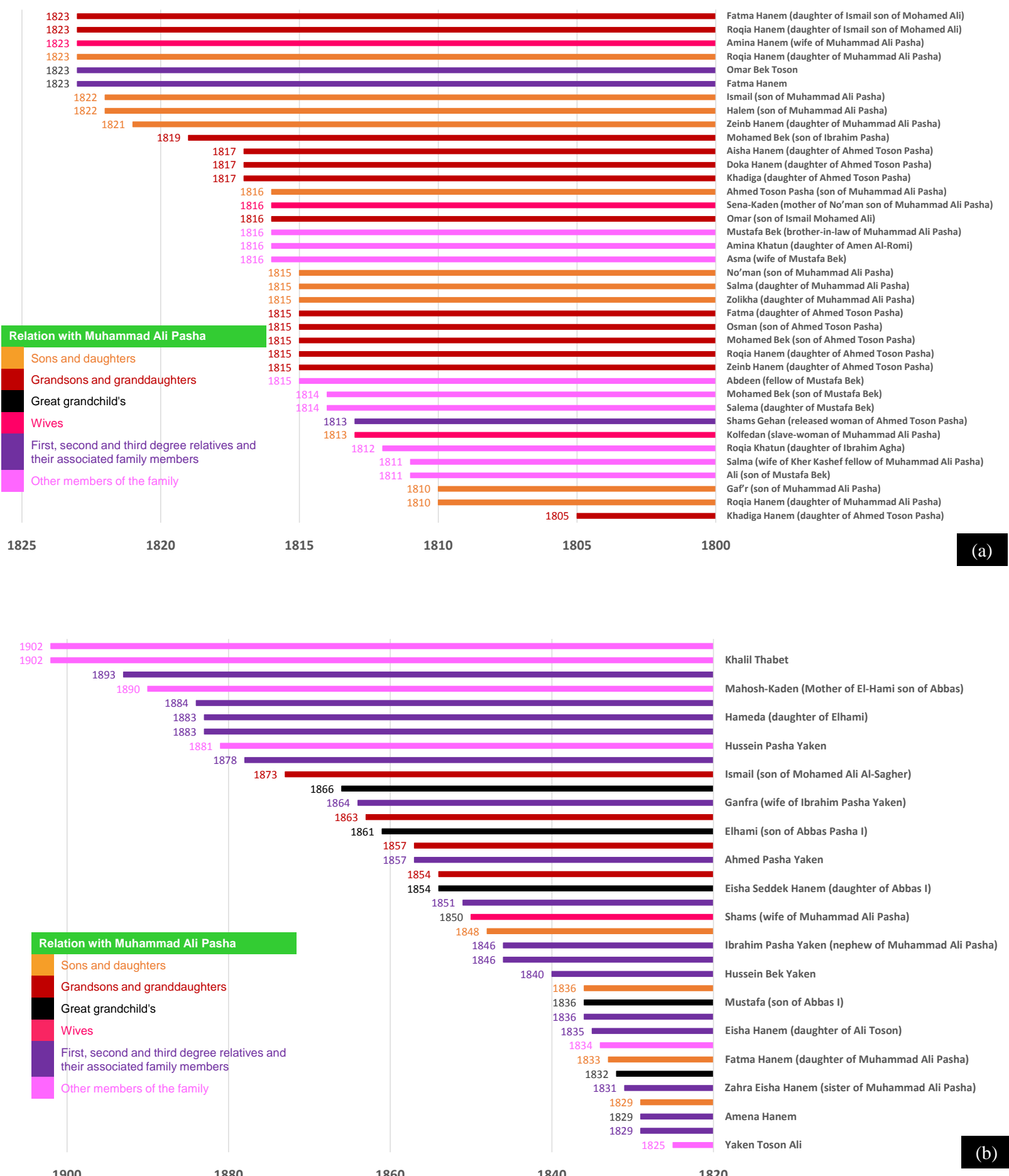

Figure 4. The relation of the buried person with Muhammad Ali Pasha and his/her death year: (a) from 1800 to 1825, (b) from 1825 to 1902 . (chart by the authors).

The Phase (III) was carried out from 1823 to 1830 in which the two rooms (6) and (7) were added, Figure 3(c). A Short time after 1830, the room (8) was added (phase IV), Figure 3(d). The room (6) received the body of Ibrahim Pasha the elder son of Muhammed Ali Pasha in 1848. 
To receive the body of Shafek-Nor Hanem who was the wife of Khedive Ismail (grandson of Muhammed Ali Pasha) the room (9) and the hall (10) were added around 1884 (phase V), Figure 3(e). Finally, king Farouk who ruled Egypt from 1936 to 1952 added the entrance area (phase VI), Figure 3(f).

\section{Description}

Hosh al-Basha occupies an area of about $2700 \mathrm{~m}^{2}$. The area of the entrance, the corridor, and the domed complex are about $1200 \mathrm{~m}^{2}$ (Figure 5(a)) and the surrounding courtyard is about $1500 \mathrm{~m}^{2}$. It has one façade located at the west and overlooks al-Imam al-Lithy street (Figure 5(b) and Figure 6). The entrance is about $6.9 \mathrm{~m}$ width and $5.8 \mathrm{~m}$ height and has a new stone masonry fence that is about $46.8 \mathrm{~m}$ length, Figure 6(a). Old photos of Hosh al-Basha indicate that the fence was not there before, Figure 6(a) and Figure 6(b).

The main gate is covered by a dome of about $5.4 \mathrm{~m}$ diameter, Figure 5(a). After accessing the cemetery gate, there are two rooms and a small bathroom at the right and other two rooms and a small bathroom at the left, Figure 5(a). This area is now used as offices for the representatives of the Ministry of Antiquities.

There is a corridor that leads from the entrance area to the domed complex, Figure 2 and Figure 5(a). The corridor is covered by five small domes of $2 \mathrm{~m}$ diameter and is supported on the columns of the two arcades of the corridor (Figure 2 and Figure 5(a)). The corridor is surrounded by a courtyard that was once a garden but now turned to be barren containing the graves of dead persons not belong to the royal family of Muhammad Ali Pasha.
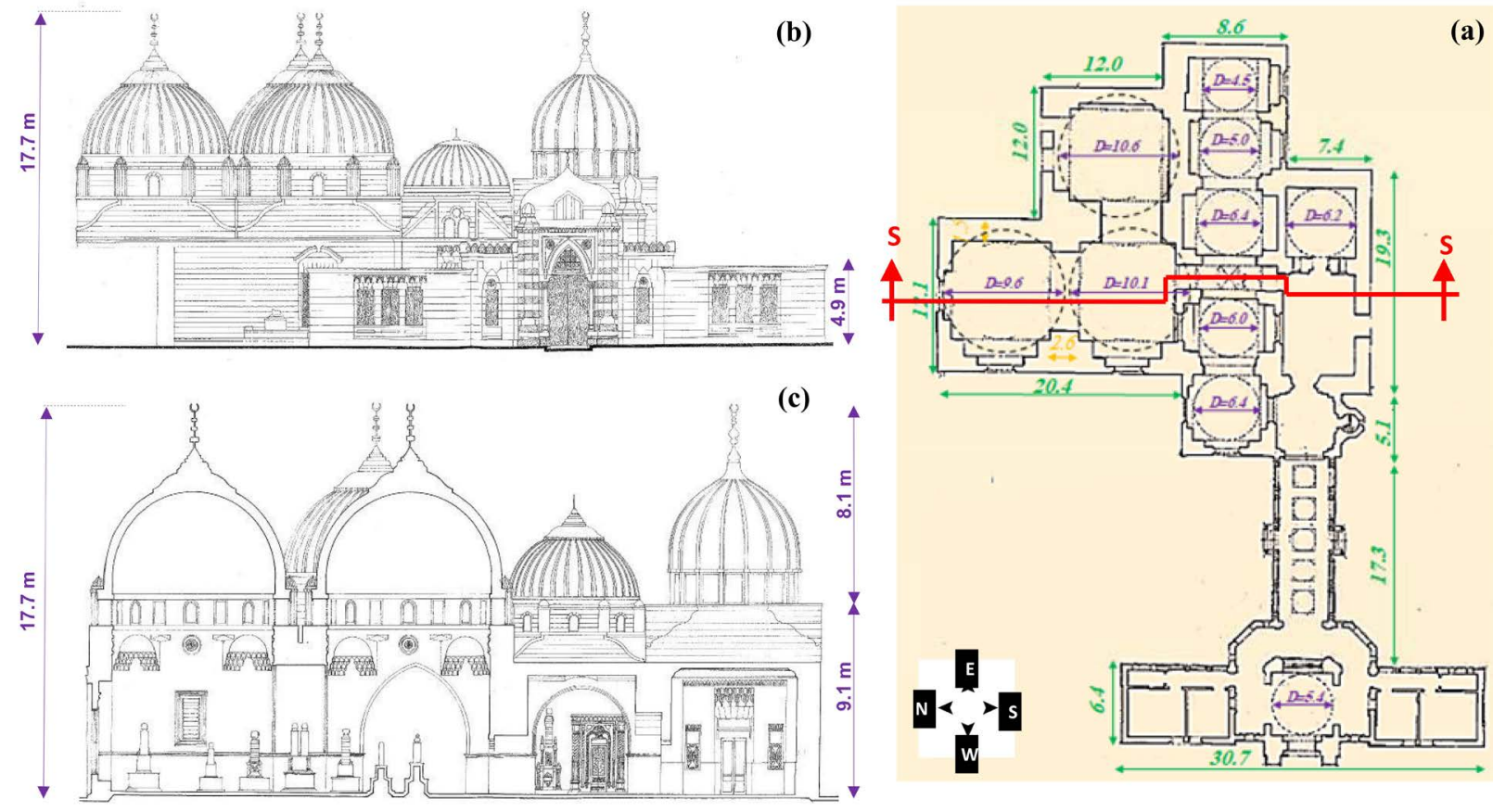

Figure 5. Hosh al-Basha architectural documentation: (a) Plan, (b) main (west) elevation and (c) section s-s. (sources of a, $\mathrm{b}$ and $\mathrm{c}$ from [17], explanations by the authors). 

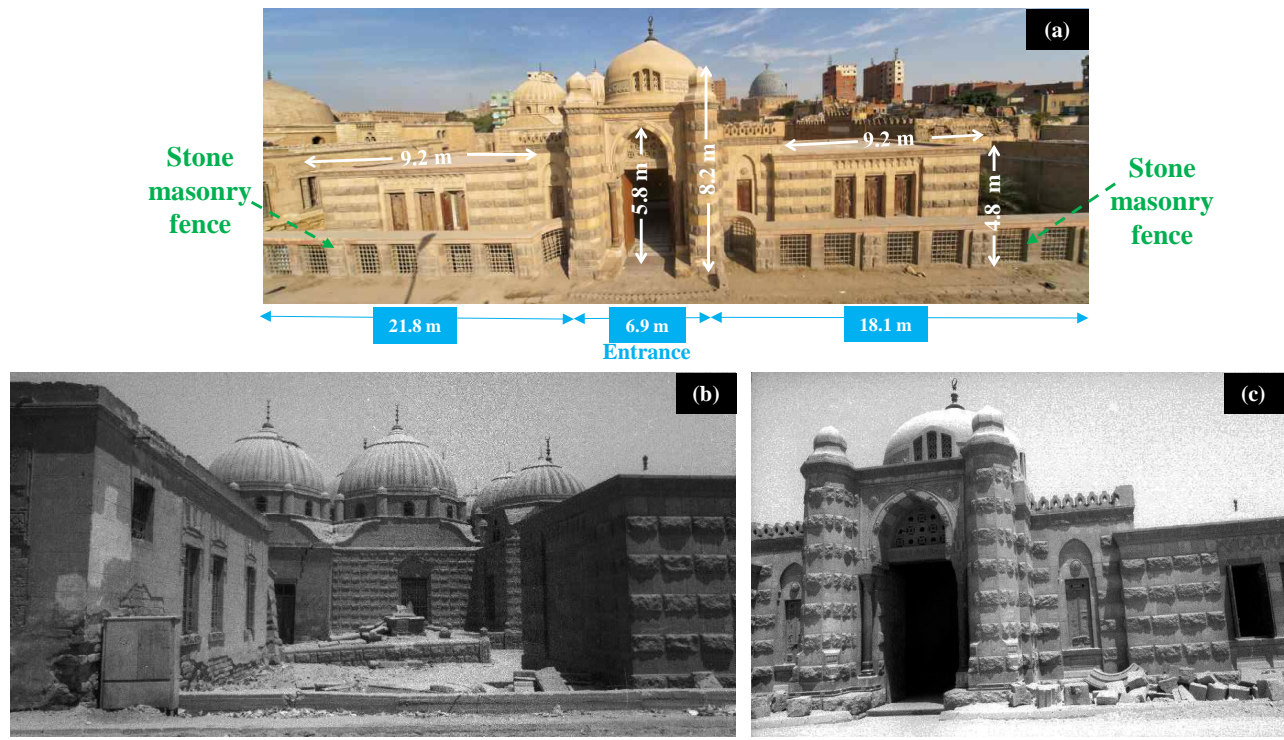

Figure 6. The main facade of Hosh al-Basha: (a) recent photo showing the stone masonry fence, (b) the left part before constructing the fence, (c) the entrance before constructing the fence. [Photo "a" is after [18], Photos "b" \& "c" date back to the last century and are after [17]. (explanations by the authors).

At the end of the corridor, there is the room (9) containing the grave of Shafek-Nor Hanem (P1 in Figure 8). This room has a square plan of about $7.4 \mathrm{~m}$ side length (Figure 5(a)). It has a unique dome that reaches a height of about $17.2 \mathrm{~m}$ (Figure $5(\mathrm{c})$ ). To the left of its entrance, there is a small corridor leads to the rooms from (1) to (5), (Figure 5(a)).

The two rooms (1) and (2) have a square plan with a side length of about 8.6 $\mathrm{m}$ (Figure 5(a)) and are covered by shallow domes (Figure 7). Some of the tombs contained within the room (2) are shown in P2 of Figure 8. The room (3) has a different dome (Figure 7) and it has the tomb of Toson Pasha the son of Muhammad Ali Pasha (P3 in Figure 8) and other tombs. The rooms (4) and (5) are covered by domes with a diameter of about $6 \mathrm{~m}$ (Figure 5(a), Figure 7) and have four tombs, one of them is for Ismail Pasha the son of Muhammad Ali Pasha (P4 in Figure 8).

The three rooms (6), (7) and (8) have a square plan of a side length of about $12 \mathrm{~m}$ and are covered by very similar domes (Figure 5(a) and Figure 7) that have a diameter of about $10 \mathrm{~m}$. Examples of the contained tombs in the rooms (6) and (8) are shown in P5 and P6 in Figure 8. The room (7) has the tomb of Ibrahim Pasha the son of Muhammad Ali Pasha (P7 in Figure 8).

From a structural point of view, the walls of Hosh al-Basha domed rooms are constructed from dressed stone masonry. In specific and as will be discussed later, the stone is limestone. The walls are thick with an average thickness of about $1.5 \mathrm{~m}$. The domes of all the rooms except the rooms (1) and (2) are hemispherical and have an average thickness of about $0.75 \mathrm{~m}$. They are rested on drums that have sufficient windows to let the light and heat enter the rooms (Figure 7). 


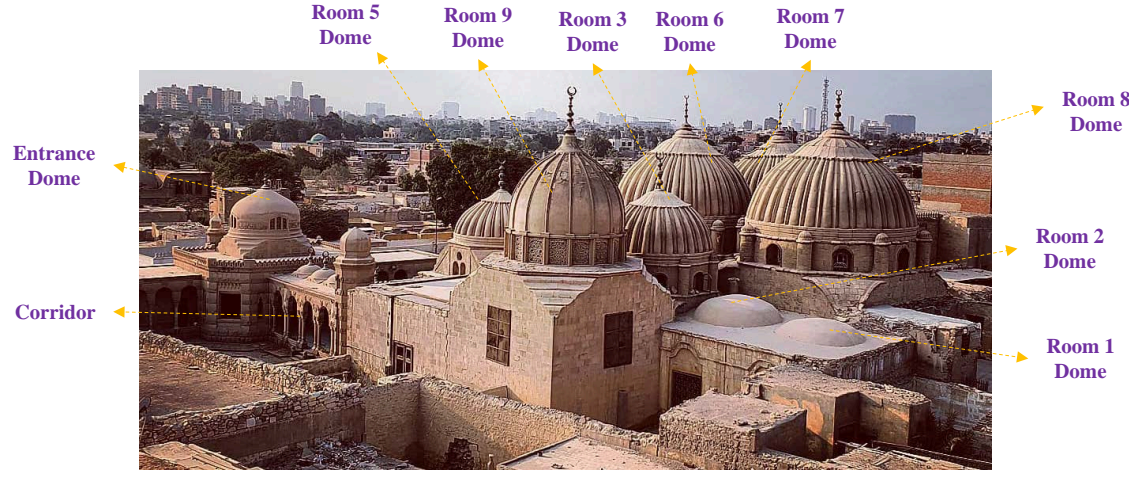

The drums are supported on squinches that transfer the domes' vertical and horizontal (thrust) reactions to the thick pointed arches that have thicknesses from about $2 \mathrm{~m}$ to $2.5 \mathrm{~m}$ (Figure 7 ).

In the rooms (1) and (2) the domes are shallow ones (Figure 7) that are supported on pendentives. In all the rooms, the vertical and horizontal (thrust) reactions of the arches are transferred to the thick walls and then to the foundation and finally to the foundation soil.

Regarding the construction technique of the tombs, Figure 9 shows a sketch illustrating very clearly the underground and aboveground components. A vaulted room with a small arched entrance exists under the ground that allows the buried body to be allocated inside the tomb. Above the ground, there is what is called "tarkeebah" that was always built from marble. It can be two levels (P5 in Figure 8) or three levels (Figure 9).

Hosh al-Basha is very rich in decorations. They are found on structural elements (walls, arches, squinches, and domes) and on the tombs. Specifically, the tombs are richly decorated using different techniques including engraved ornamentation (Figure 10(a)), floral motifs (Figure 10(b)), and gelded stucco (Figure 10(e)). Colored wall paintings and colored glass are also used (Figure 10(c) and Figure 10(d)). The decorations on the tombstone indicate the rank and the sex of the buried person. Braids in relief, painted braids (Figure 11(a)) and a coil of loosely caught hair indicate a royal mother, a royal wife and a virgin princess, respectively. Turbans or fezzes indicate men (Figure 11(b)) [19].
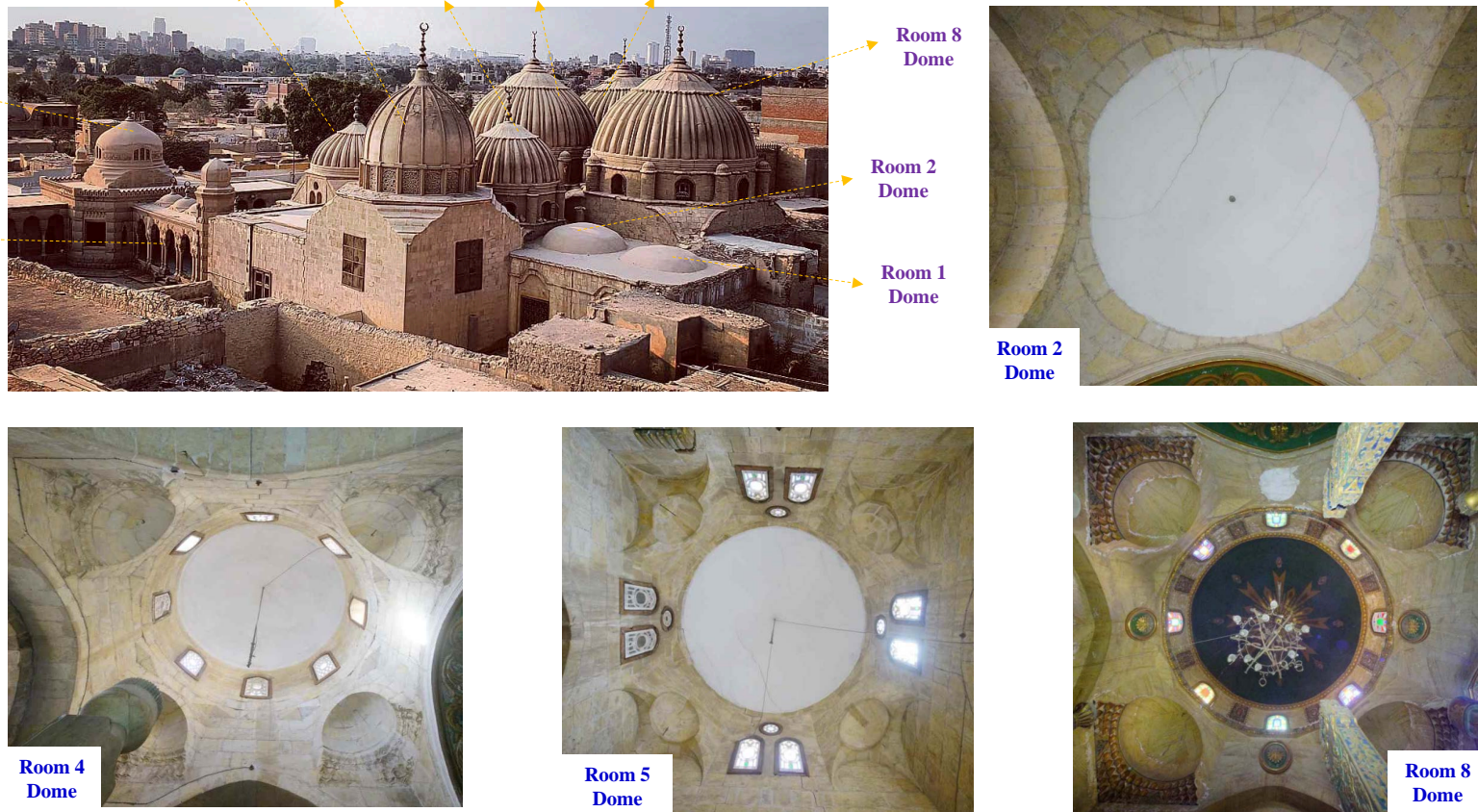

Figure 7. External view of Hosh al-Basha (as seen from al-Imam al-Shafi'i mausoleum) showing the rooms' domes, and the domes of the rooms (2), (4), (5) and (8) from inside. (Photo sources [18] and [20], explanations by the authors). 


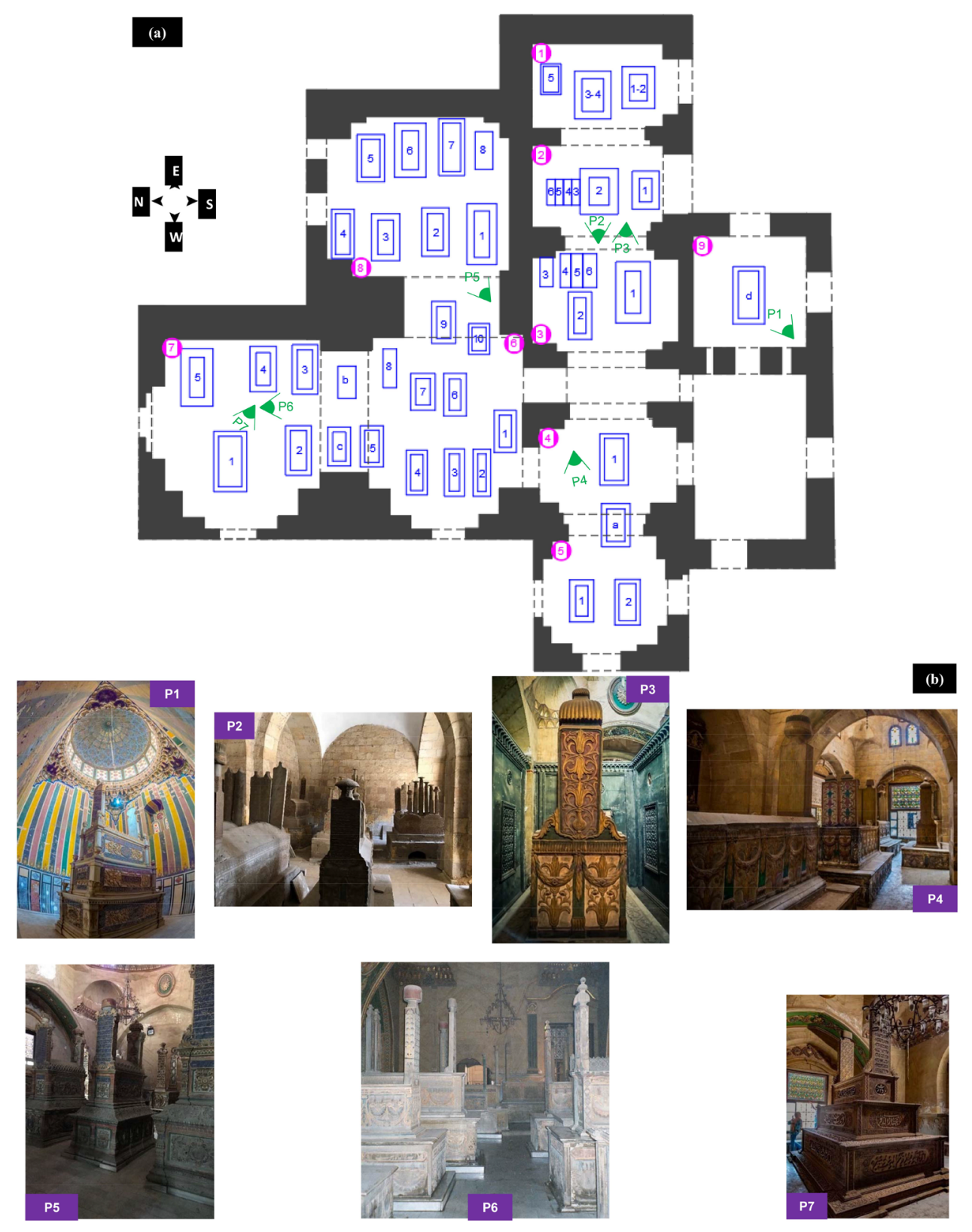

Figure 8. (a) Plan showing the distribution of the tombs inside the rooms, (b) Inside photos of some the tombs: (P1) room (9), (P2) rooms (1 and 2), (P3) room (3), (P4) rooms (4 and 5), (P5) room (8), (P6) rooms (6 and 7), (P7) room (7). (explanations by the authors).

\section{Damage Symptoms and Causes}

Hosh al-Basha suffers from obvious on-going deterioration of the construction materials; in addition, it manifests clear structural problems affecting its overall stability. Wide, long, and extended cracks can be visible in the domes, the drums, the squinches, the arches, and the walls of the different cemetery's rooms. The walls and the tombs suffer from dampness due to the rising of the groundwater by the capillary action. In the next paragraphs, more detailed damage inspection findings and their possible causes are discussed. 


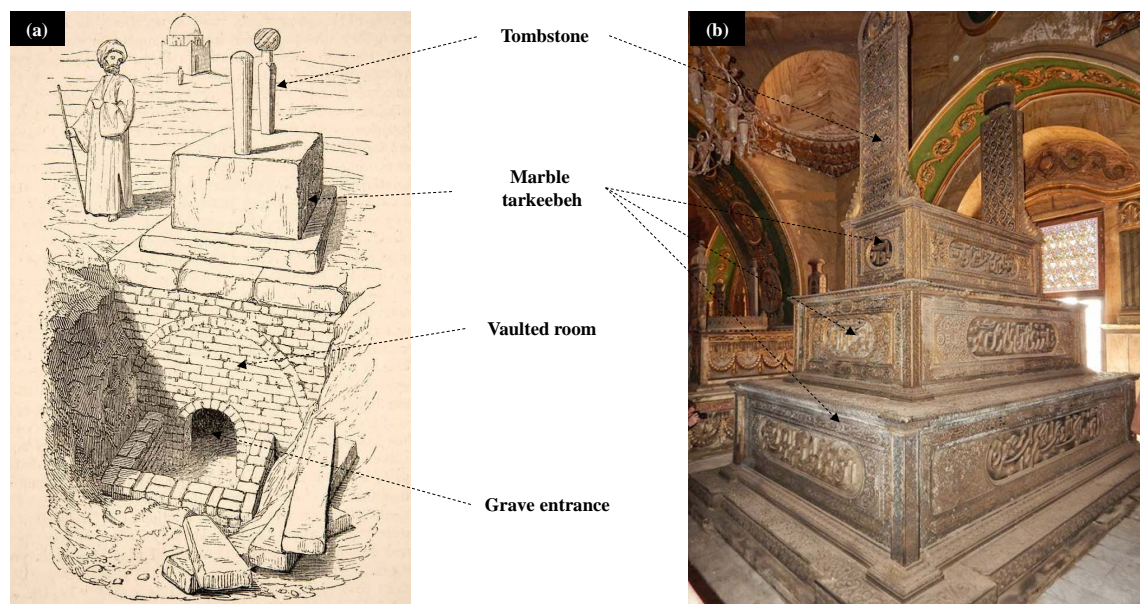

Figure 9. (a) A sketch dating to the 18th century showing the components of a tomb by [21], (b) illustrations for Ibrahim Pasha tomb. (explanations by the authors).
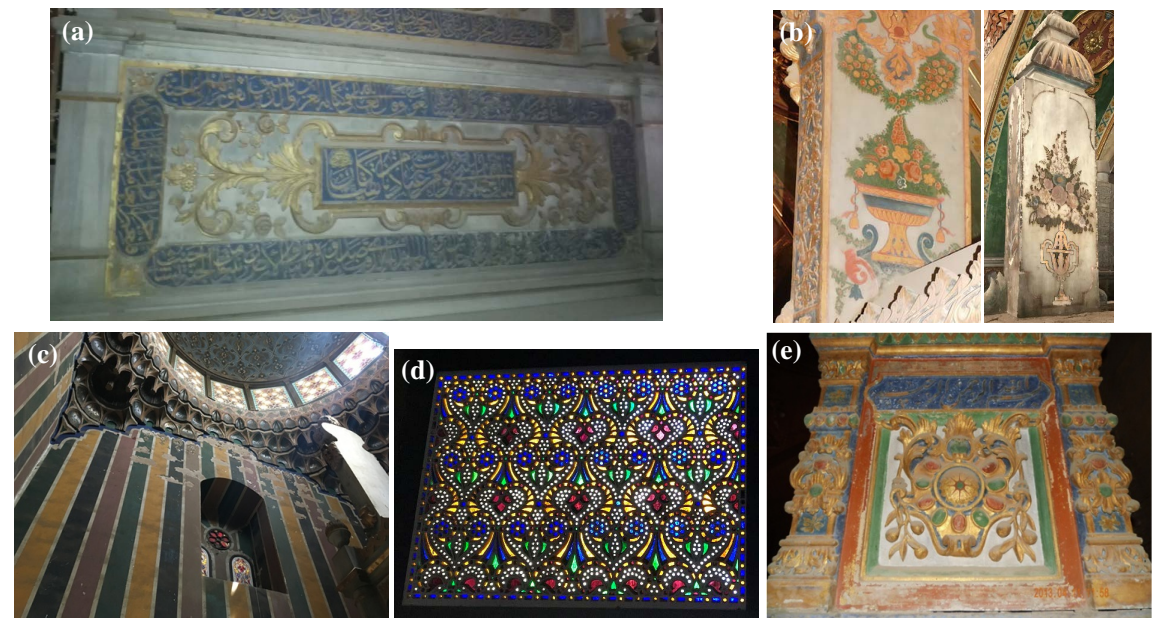

Figure 10. Several examples of the decorations in Hosh al-Basha: (a) written and floral ornamentation engraved on marble, (b) floral motifs, (c) wall paintings, (d) colored window glass, (e) gelded stucco. (photos by the authors).
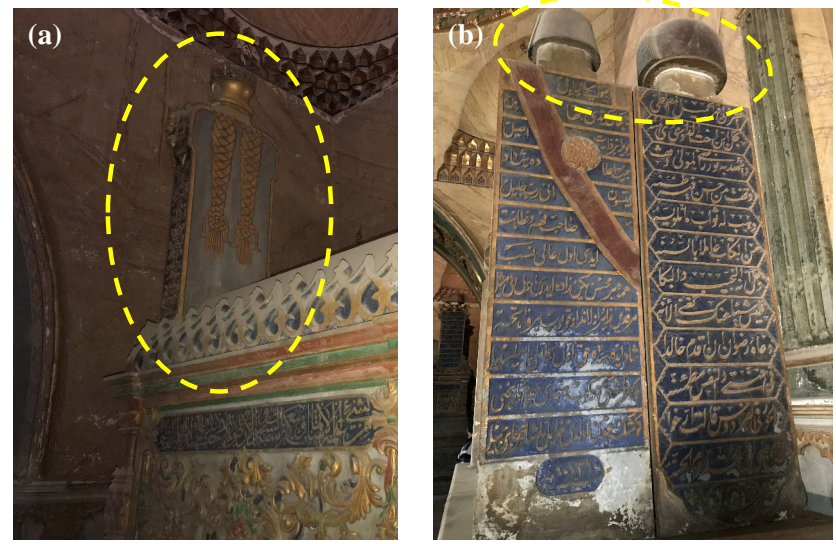

Figure 11. (a) Painted braid indicating buried female, (b) a turban and a fezze indicating buried males. (photos by the authors). 


\subsection{Groundwater-Induced Damage}

The main cause of the observed damage in Hosh al-Basha is the continuing increase in the level of the groundwater in the foundation soil. For the location of Hosh al-Basha, in particular, there is a further harmful effect from the nearby natural water pools of "Ain al-Sira" and "Khayalat Al-Shorta". Kamel (2004) [22] in his study about these two pools and the surrounding areas (including Hosh al-Basha) revealed that the groundwater level is continually increasing. The level increased about 0.5 to $1.0 \mathrm{~m}$ from the natural ground level. This was due to several reasons: 1) a new habitant project in the area, 2) absence of sewage system or septic tanks for some unplanned urban areas, and 3) the leakage from the existing sewerage and water supply systems. This in turn resulted in an increase of the salinity due to the increase in the anions of chlorides $\left(\mathrm{Cl}^{-}\right)$, sulfates $\left(\mathrm{SO}_{4}^{-2}\right)$, and bicarbonates $\left(\mathrm{HCO}^{-3}\right)$. In addition, the cations of $\mathrm{Na}^{+}, \mathrm{K}^{+}, \mathrm{Ca}^{++}$, and $\mathrm{Mg}^{++}$were found in the chemical analyses of the water of the two pools [22].

As an important conclusion of the study of [22], he divided the surrounding areas of the two pools into medium dangerous zones and very dangerous zones. Hosh al-Basha lies in the very dangerous zone in which the rise of the groundwater level exceeded $50 \mathrm{~cm}$ (from 1994 to 2004) and the percentage of $\mathrm{SO}_{4}^{-2}$ is high. The saline groundwater badly affects the foundations and leads to its decay in the long term.

The rise of the groundwater by capillarity inside the walls of Hosh al-Basha is clearly noticed. In Figure 12, the comparison between an old photo and a recent one shows how the groundwater raised in the east wall of the room (7). Because of this rise, the salts penetrated with the groundwater inside the stone masonry wall. Afterward, the groundwater evaporated and the salts crystallized which led to internal stresses in the stone resulting in its deterioration and failing of its marble casing. Finally, the salts effloresced on the stone surface distorting its appearance (Figure 12(a)). In the same Figure, one can notice the groundwater rise in the walls from outside and the discoloration and the blackening of the stone as a result. Some other observations of the same phenomena of stone deterioration can be noticed in Figure 13.

The stone was badly affected by the groundwater rise and different deterioration symptoms were noticed (Figure 14). Those included granular disintegration and losses of stone layers, losses of crusts and salt efflorescence, losses of scales, stone soiling by atmosphere particles, subflorescence.

Hosh El-Basha tombs have many wall paintings whether directly applied at the stone masonry walls or at layers of plaster; both of them are in very bad conditions. Because of the groundwater rise in the walls, the paint layers suffer from severe deterioration such as discoloration, detachment, and loss of some pieces (Figure 15). Physiochemical factors and biological agents increase the effect of groundwater by causing a remarkable amount of aesthetical and chemical damage. Different types of dirt accumulate, such as dust, stains, insect's remains, and 
house flyspecks are deposited on the painting surface. In addition to crumbling in some parts of paint and fine network of cracks is present through the paint and the ground layers. Some previous interventions were done by painting the walls with a lime layer that concealed the original drawings. This lime layer was deteriorated, peeled, and revealed these original drawings (Figure 15(c)).
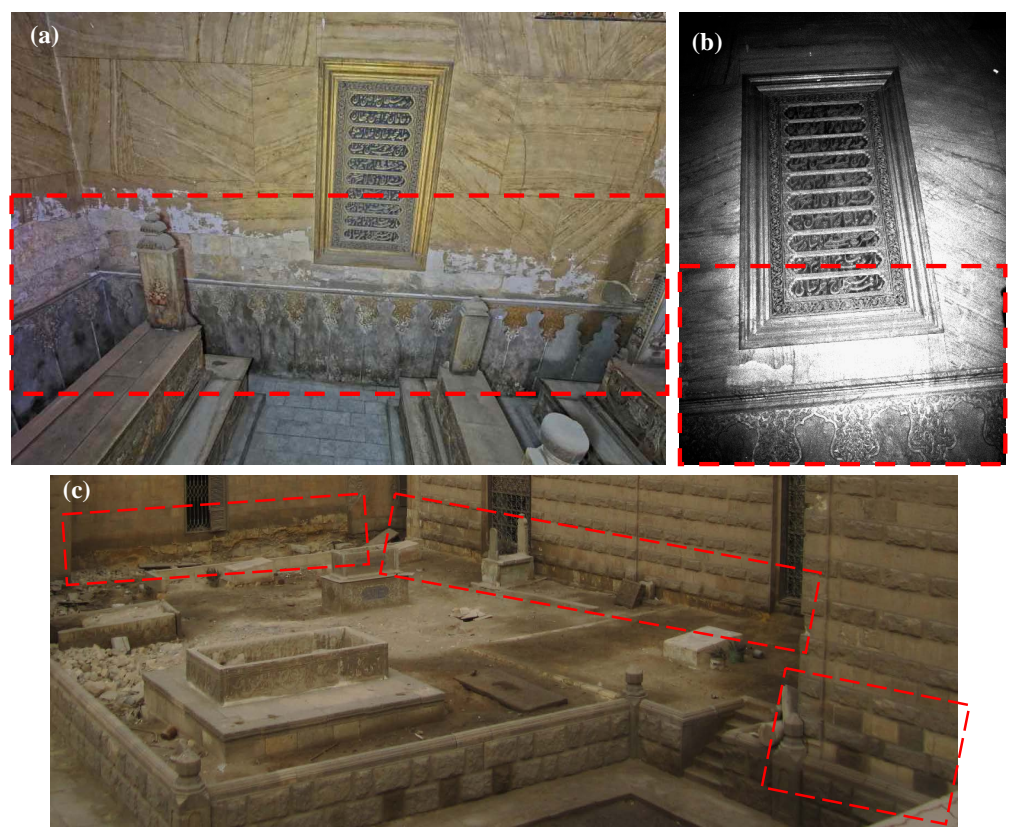

Figure 12. (a) groundwater rise by capillarity in the east wall of the room (7), (b) old photo of the same wall showed lesser rise and damage, (c) groundwater rise by capillarity in the outside of the walls of the rooms (5), (6), (7) and the adjacent building. (photo "a" by [18], photo "b" after [17], explanations by the authors).
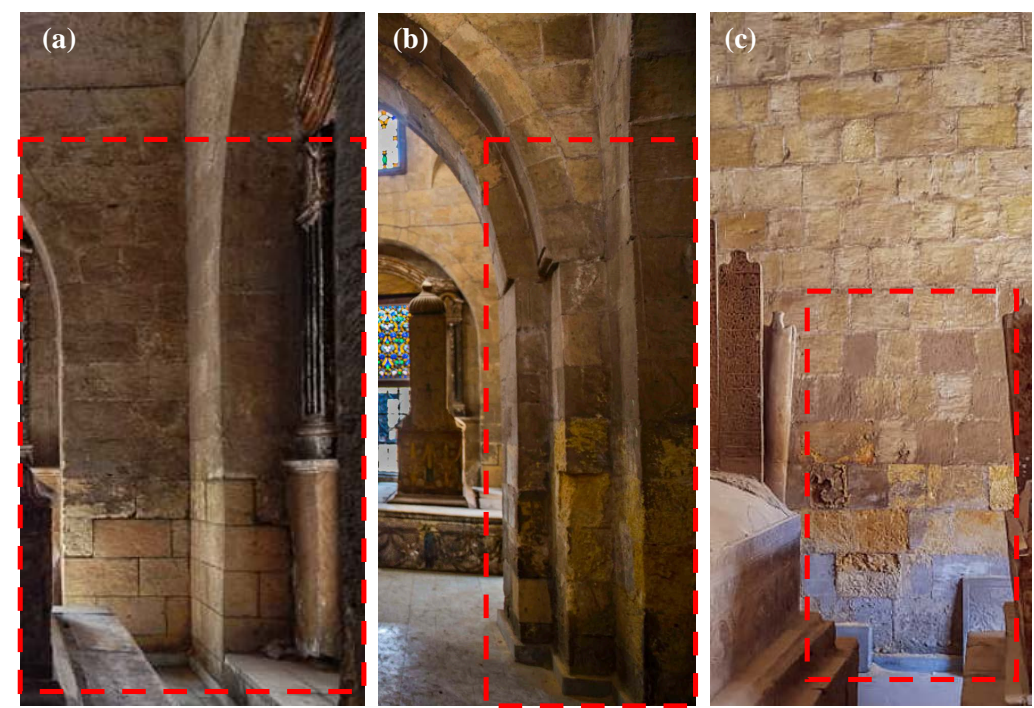

Figure 13. Evidences of the damage due to the groundwater rise inside the walls of Hosh al-Basha: (a) the west wall of the room (5), (b) the arch between the rooms (4) and (5), (c) the east wall of the room (1). (photos by the authors). 

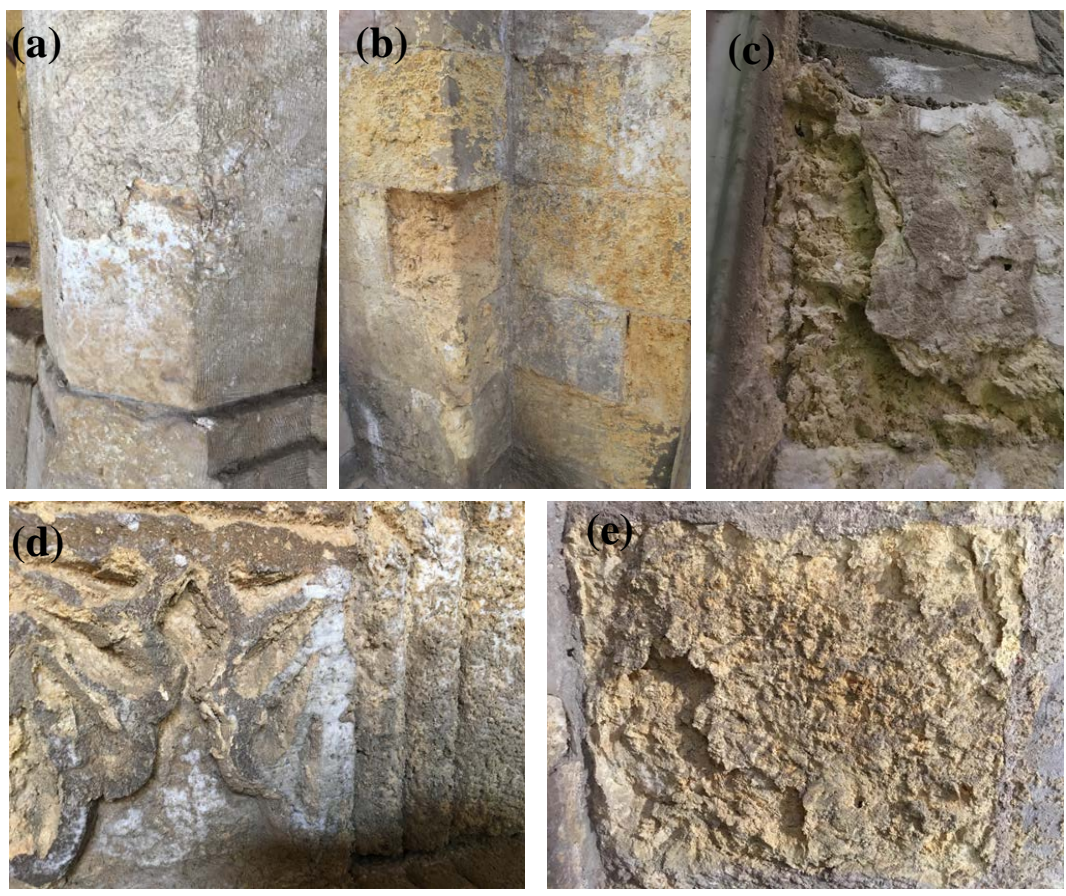

Figure 14. Different groundwater-induced damage patterns of the limestone of Hosh al-Basha: (a) granular disintegration and losses of stone layer, (b) losses of crusts and salt efflorescence, (c) losses of scales, (d) subflorescnece, (e) efflorescence and soiling by particles from the atmosphere. (photos by the authors).
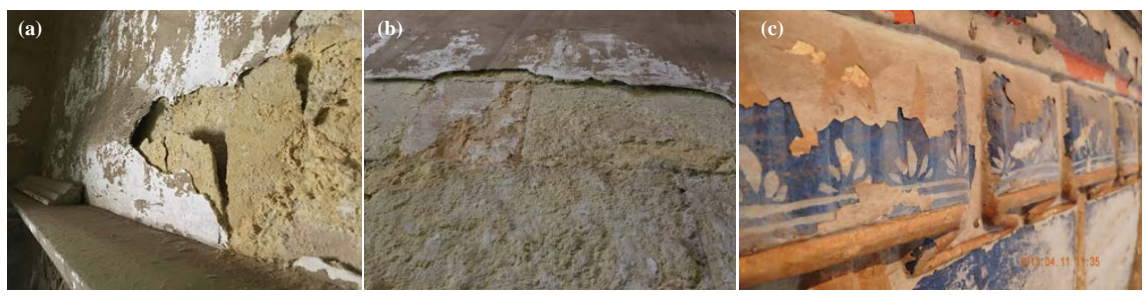

Figure 15. Deterioration symptoms of the wall paintings of Hosh al-Basha in the form of: (a) detachment of the paint layer from the ground layer, (b) pieces of both layers were lost, (c) the lime layer deteriorated, peeled and revealed the original blue decorations.

The groundwater-induced damage is clearly noticed in the marble elements. Distributed cracks of different depths and forms can be seen and are more obvious in the lower parts near the ground. The marble casing and slabs show massive efflorescence, due to the surface salt crystallization (Figure 16(a)). The detachment of smaller stone elements from large-sized elements, flaking on the edges, and granular disintegration is noticed clearly (Figure 16(b)). Large areas of the marble layer became very fragile and completely detached from the background of the stone masonry walls (Figure 16(c)). Different types of dirt accumulate are deposited on the marble surface which can cause the marble to deteriorate further and distorts the marble's decorations (Figure 16(d)). Due to the settlement of the foundation soil beneath the marble slabs at the corridor, it manifests cracking (Figure 16(e)). 

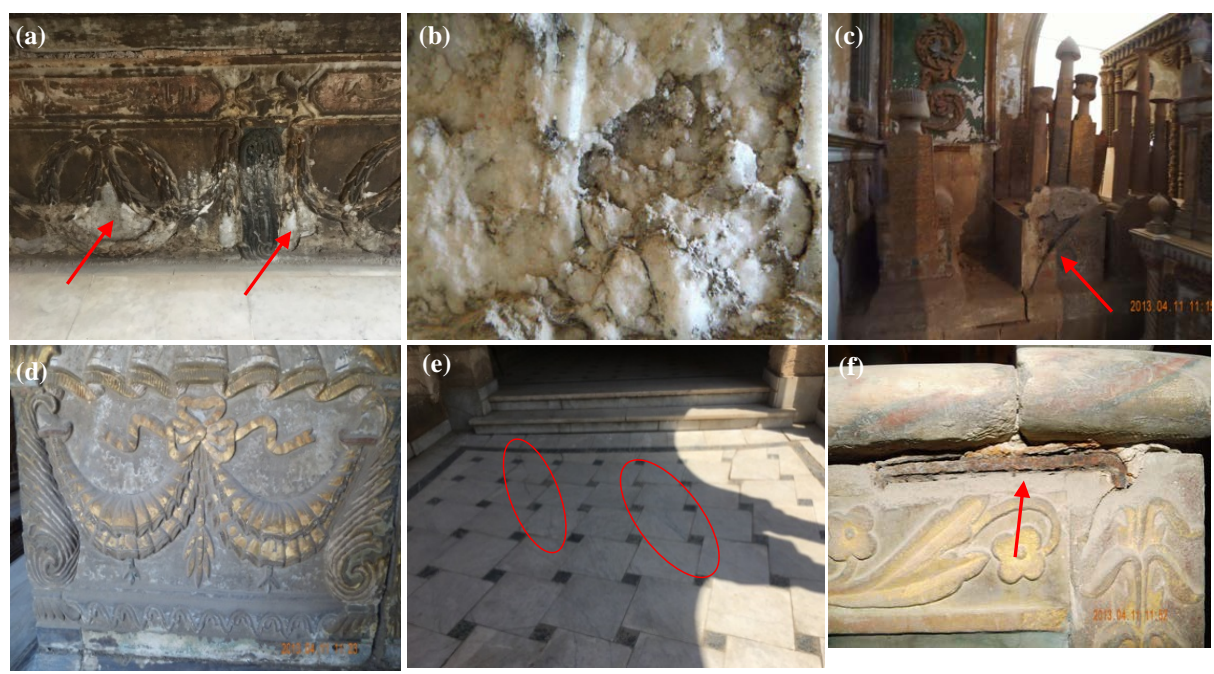

Figure 16. Symptoms of the damage of the marble elements in Hosh al-Basha: (a) cracks and salt florescence, (b) loss of stone material, detachment, flaking and granular disintegration, (c) detachment of marble, (d) dirt accumulate, (e) cracking due to settlement, (f) previous restoration using iron bars.

Previous restoration using iron bars to connect cracked marble elements are noticed, however, due to surrounding conditions of air and humidity in conjunction with groundwater rise, the iron oxidized and converted to hydroxide with considerable volumetric increase and as a result, it cracked the marble around (Figure 16(f)).

\subsection{Differential Settlement Damage}

The damage manifested by Hosh al-Basha's structural elements due to the foundation decay and differential settlement was surveyed. In Figure 17, a comparison is made between old photos dating back to the last century and recent ones of the arch, the short wall, and a previous room existing in the courtyard.

As can be noticed the arch and the short wall manifested large deformations and the room's walls suffered from large cracks. It seems that the room collapsed; however, the arch and the short wall were restored by dismantling and re-constructing.

It appears that the foundation soil in this area is going large deformations affecting Hosh al-Basha and the adjacent buildings until today. In Figure 18, recent photos show the serious tilting of a wall behind the arch. The same wall has also serious diagonal cracking.

In Figure 19, it can be noticed the north wall of the room (7) suffers from diagonal cracking above its window. The adjacent building as well suffers from serious diagonal cracking above its door and window. For the same room, the east wall is diagonally cracked (Figure 20(a)). Besides, the west wall is cracked from outside (Figure 20(b)) and inside (Figure 20(c)), it seems that the crack is recent as an old photo did not show it (Figure 20(d)). 

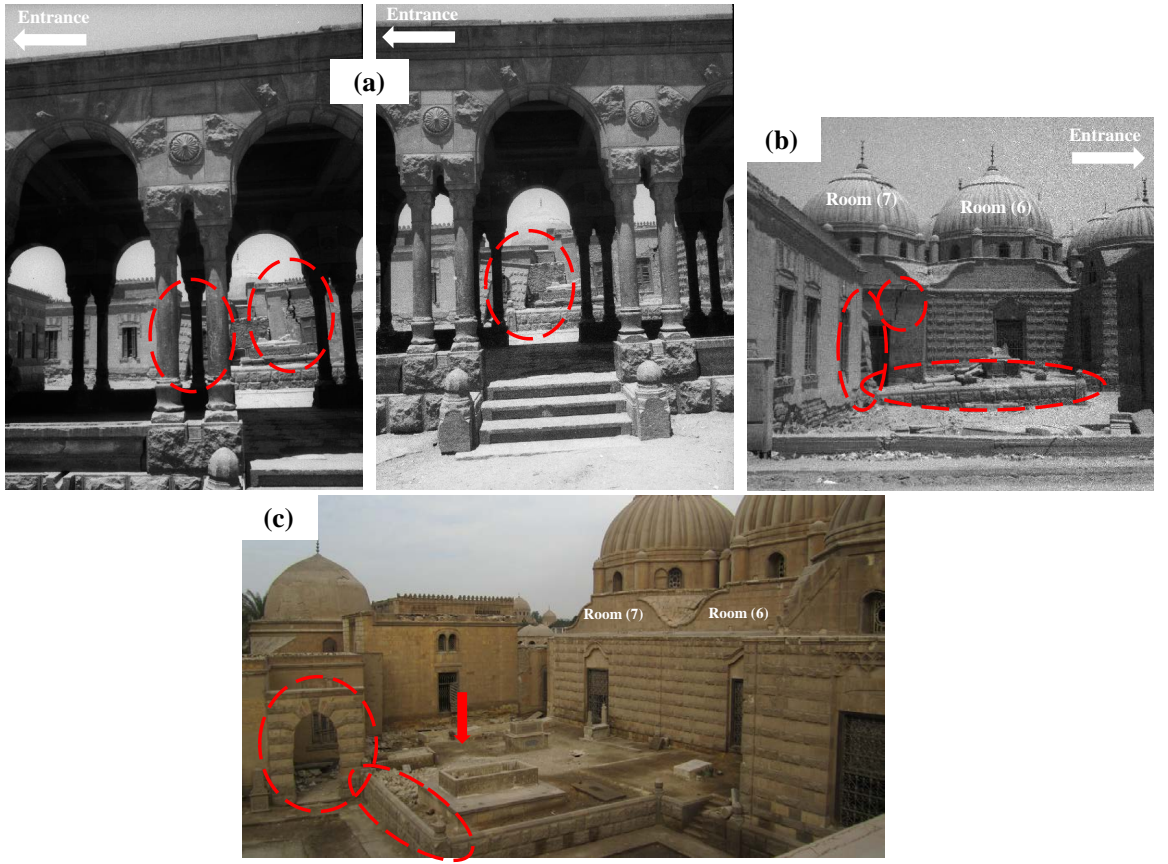

Figure 17. The effect of the differential settlement: (a) large deformations of the arch and large crack in the wall (looking north), (b) looking east at the arch, the wall and the short wall, (c) the current situation of the arch and the short wall and the disappearance of the room. (the old photos are after [17], explanations by the authors).
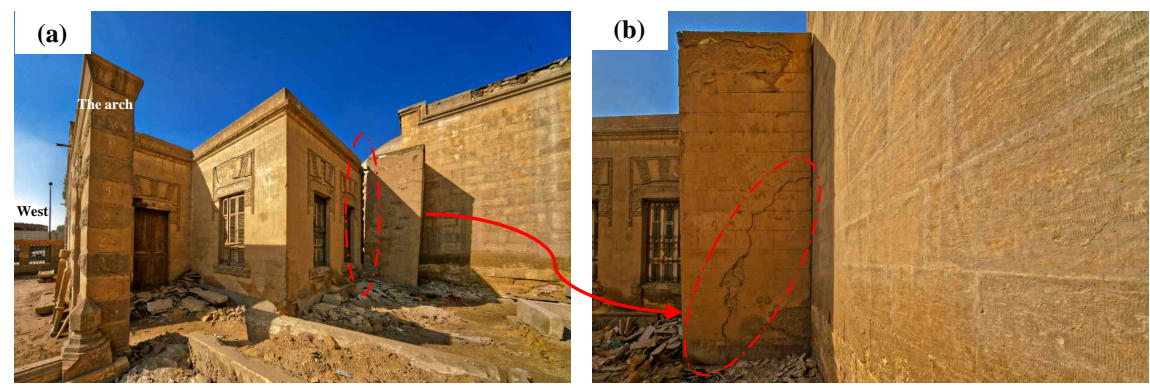

Figure 18. Serious deformations and cracking in the existing walls at the collapsed room area: (a) serious tilting, (b) diagonal cracking. (photos by [18], explanations by the authors).
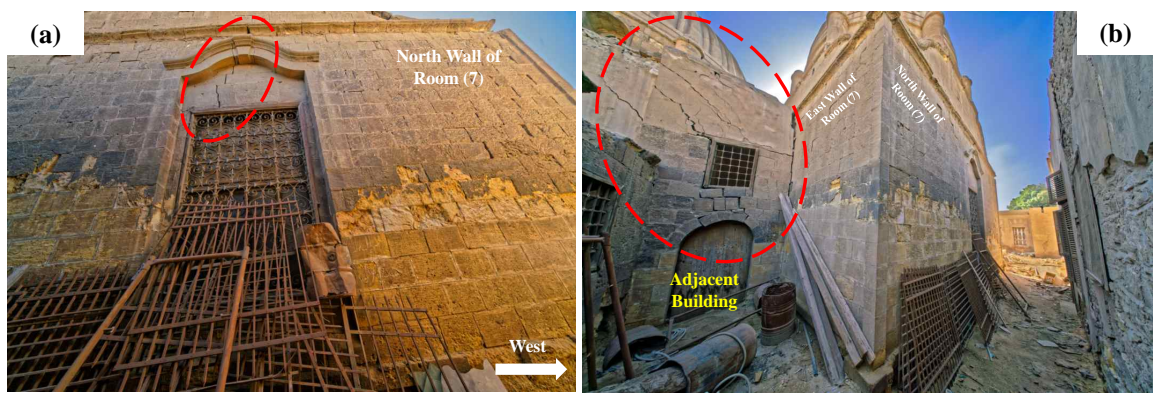

Figure 19. The differential settlement cracking at the room (7) and the adjacent building: (a) diagonal cracking, (b) adjacent building diagonal cracks. (photos by [18], explanations by the authors). 

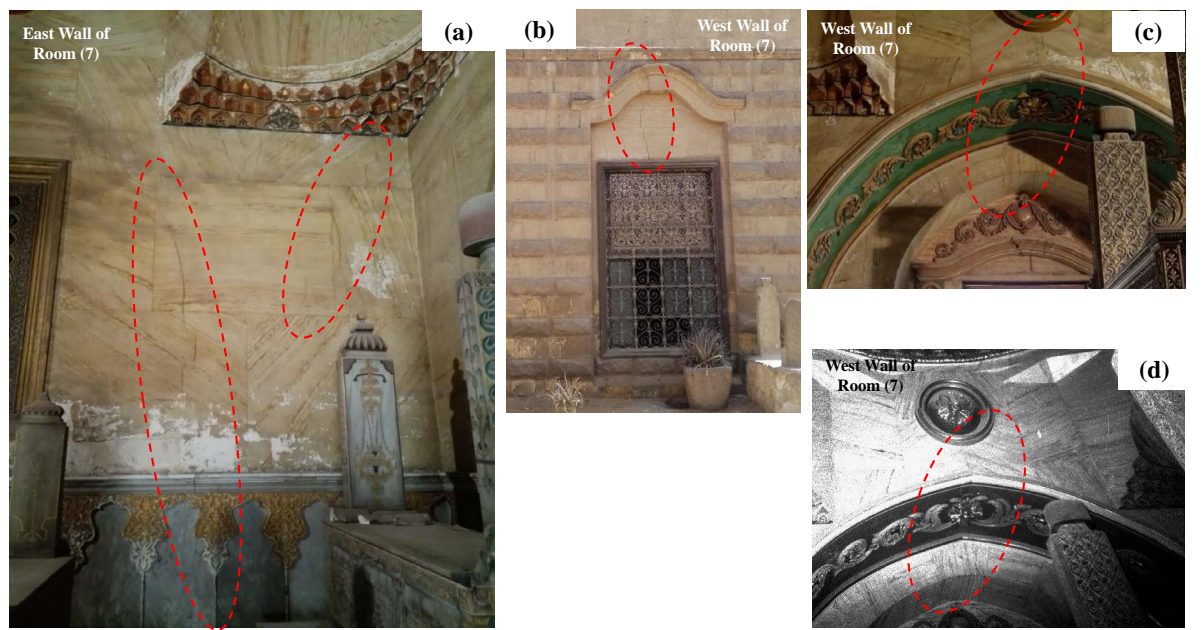

Figure 20. Cracking of room 7 walls: (a) cracking of the east wall, (b) cracking of the west wall from outside, (c) cracking of the west wall from inside, (d) old photo shows no cracking. (the old photo is after [17]).

One can notice the visible wide cracks in the dome of the room (1) and the tombs (Figure 21(a)). In the room (2), the dome is also cracked and the crack is extended and visible from the intrados and the extrados (Figure 21(b) and Figure $21(\mathrm{c})$ ), as well, the north wall has a typical long diagonal crack due to the differential settlement (Figure 21(d)).

The north wall of the room (3) has a long vertical wide crack (Figure 22(b)) that starts from the arch middle and extends to the wall. This crack did not exist before as can be observed from an old photo dates back to the last century (Figure 22(a)). At the back of this wall, the arch between the two rooms (6) and (8) exist (refer to the plan in Figure 8(a)). The arch is heavily damaged from the ground to above the springing with multiple diagonal cracks (Figure 22(c)). The gypsum telltale mounted on the crack to monitor its movement was found broken indicating its on-going movement and widening (Figure 22(c)) due to the differential settlement. It is interesting to confirm the on-going damage by looking to Figure 23 in which the dome of the room (3) has an old photo and a recent one. The recent cracks can be easily identified. The south wall of the room (8) has a diagonal crack (Figure 24(a)) and the two south squinches as well are cracked, Figure 24(b) \& Figure 24(c).

The differential settlement damage is affecting the dome of the room (4) and the supporting drum and arch as indicated in Figure 25. The typical diagonal cracking is noticed passing through the weak plane of the mortar joints affecting both of the arch intrados and the dome drum.

The cracking of the structural elements of the room (5) seems to be also in progress as can be noticed from the comparison shown in Figure 26. The old photos did not show the observed damage nowadays. A More detailed focus on the cracking of the south and north parts of the room is shown in Figure 27. The differential settlement affected tomb number 2 that was cracked as indicated in Figure 28(a) and Figure 28(b) as observed in the year 2018. Fine restoration 
works were carried out after 2018 and recovered the original integrity and colors as can be noticed in Figure 28(c).
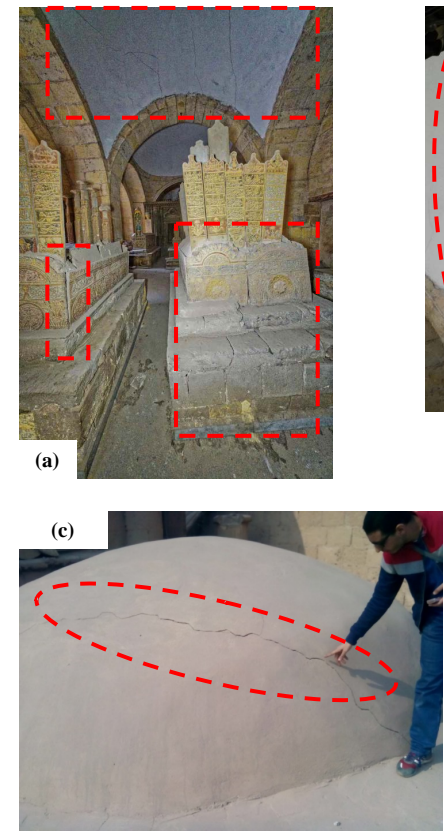

Figure 21. (a) The observed damage in the room (1); (b), (c) and (d) the observed damage in the room (2). (photo "a" by [18]).

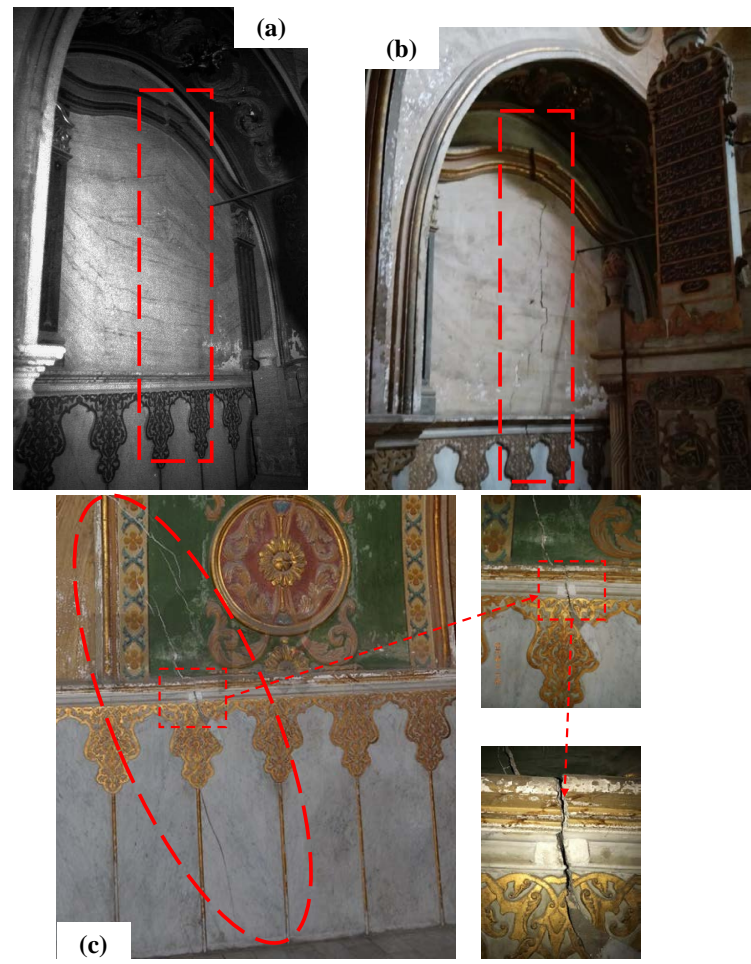

Figure 22. The observed damage in the room (3) and the arch between the rooms (6) and (8): (a) old photo before cracking, (b) cracking in the north wall of the room (3), (c) cracking in the arch between the rooms (6) and (8). (the old photo is after [17]). 


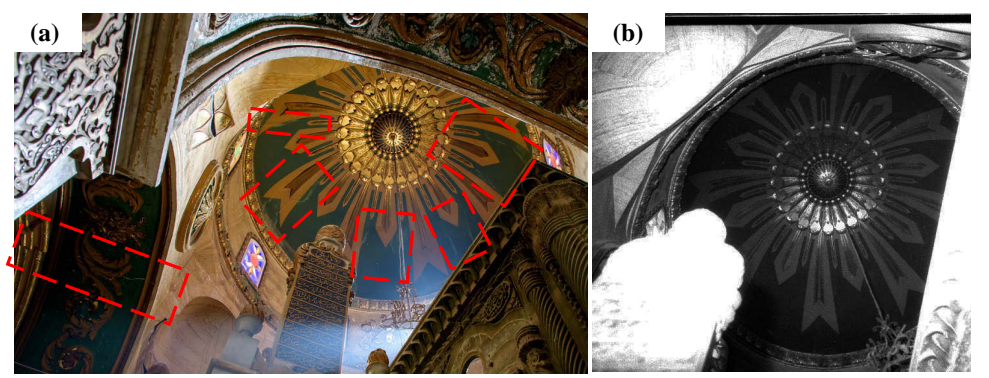

Figure 23. Recent damage of the dome of the room (3): (a) cracking in the dome, (b) old photo of the dome showed no cracks. (the old photo is after [17]).
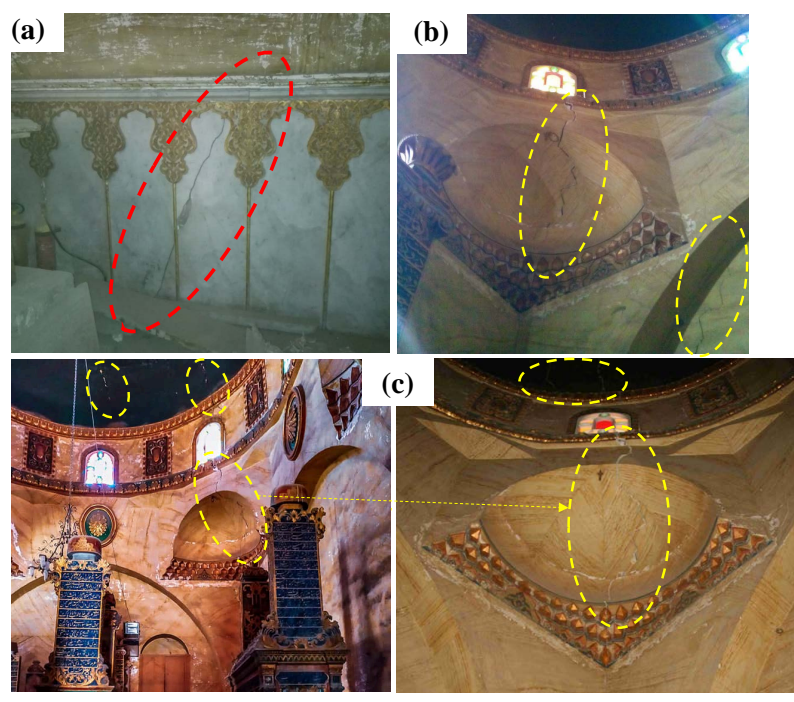

Figure 24. The observed damage of the room (8): (a) cracking in the south wall, (b) cracking in the south west squinch, (c) cracking in the south east squinch. (explanations by the authors).

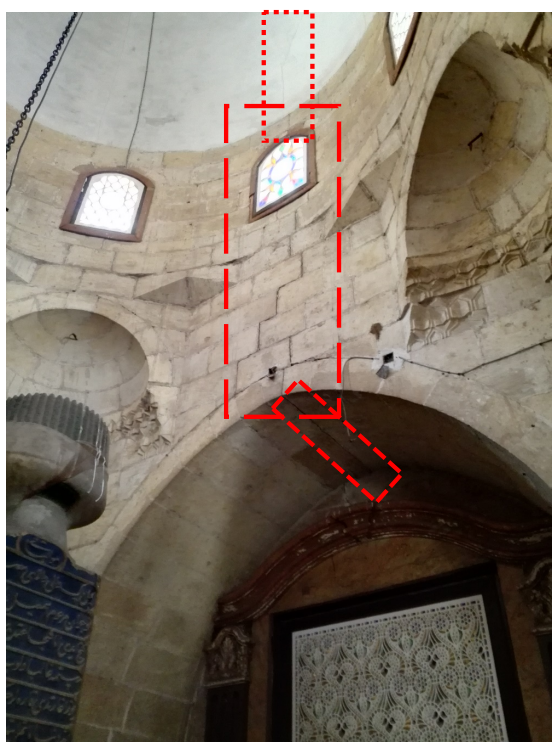

Figure 25. Structural damage of the dome and its supporting drum and arch in the room (4). (explanations by the authors). 

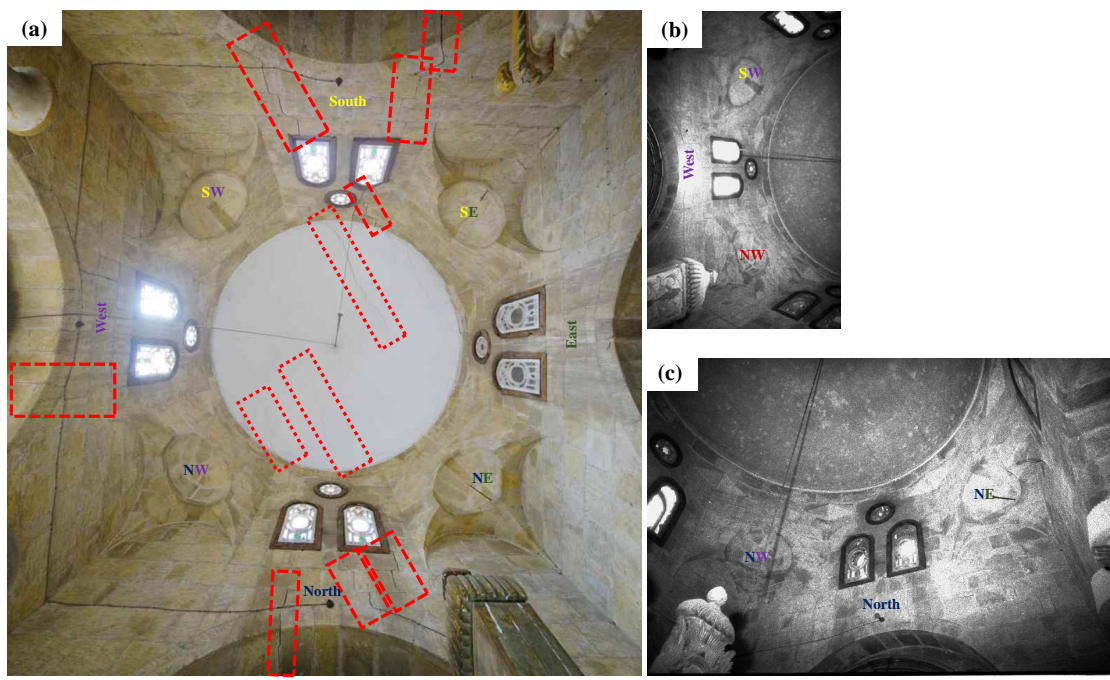

Figure 26. Structural damage of the room (5): (a) cracking of the dome, the drum and the arches, (b) old photo of the west side showed no cracking, (c) old photo of the north side showed no cracking. (photo "a" by [18] and the old photos are after [17], explanations by the authors).
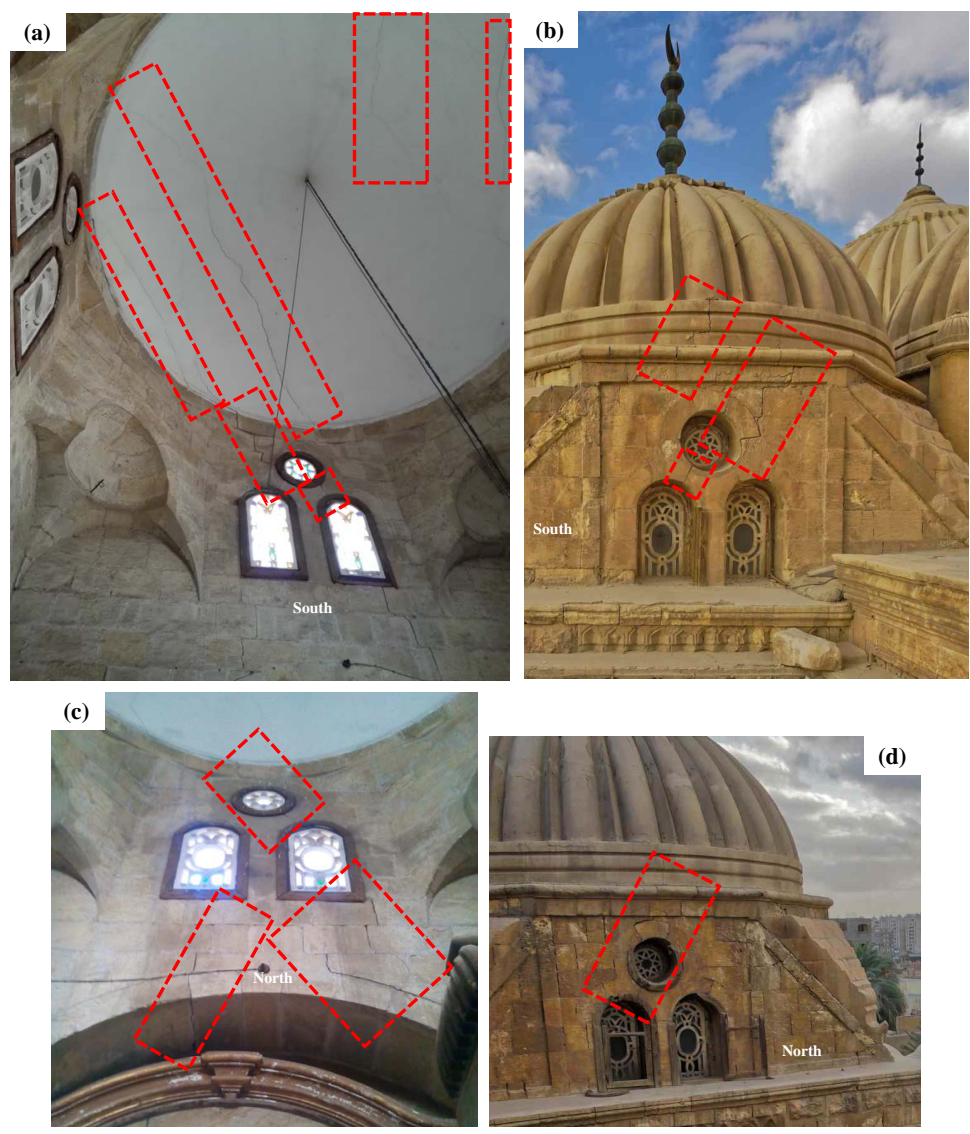

Figure 27. The damage of the room (5): (a) cracking of the dome and the drum from the intrados (south part), (b) cracking of the dome and the drum from the extrados (south part), (c) cracking of the dome and the drum from the intrados (north part), (d) cracking of the dome and the drum from the extrados (north part). (explanations by the authors). 

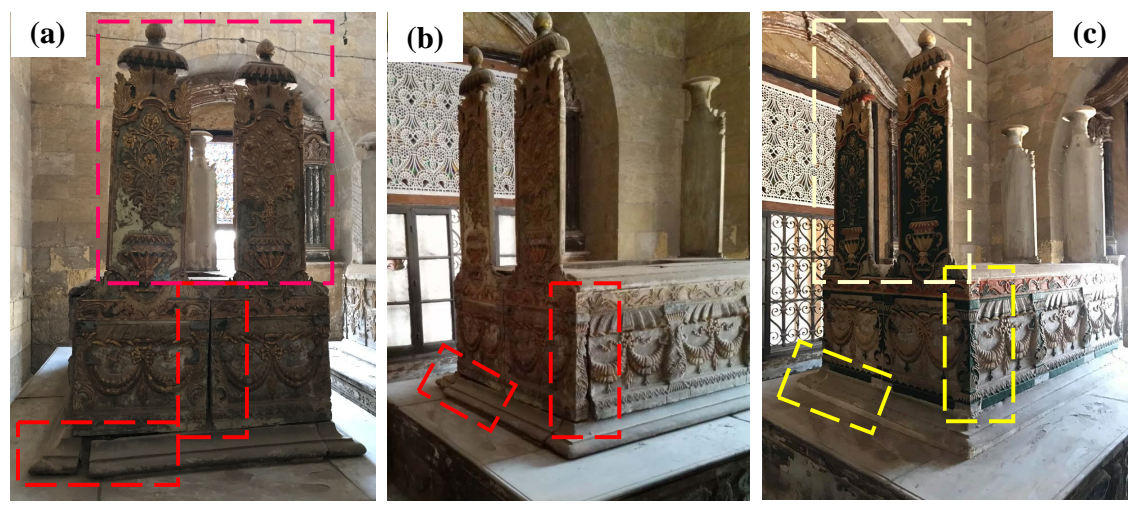

Figure 28. The cracking and the discoloration of the tomb number 2 in the room (5): (a) and (b) before restoration in 2018, (c) after restoration in 2020. (explanations by the authors).

\subsection{Construction History and Lack of Maintenance}

The construction sequence of the cemetery is one of the reasons for the observed damage. As previously discussed, the cemetery was enlarged by adding the rooms one after another. Therefore, some of the observed damage nowadays can be related mainly to the history of the construction. This damage is seen in the form of separation cracks as that one between the room (5) and the corridor (Figure 29(a)), the crack between the rooms (3) and (4) (Figure 29(b)), and the crack between the room (9) and the corridor (Figure 29(c)).

This sort of cracks is common in historical structures built in consequent phases. An interesting example is the Mallorca cathedral, one of the largest ever-built historical stone masonry structures in the world. This cathedral has a major separation crack due to the interruption during its construction [23]-[31].

These cracks appeared either because of the lack of connection between the older parts and subsequently added parts. Alternatively, because of the different deformations of the foundations of the older parts and subsequently added parts. It should be noticed that the foundation depth, size, and materials of the older parts and subsequently added parts might not be identical; therefore, their deformations also may not be identical which results in the observed separation cracks. It should be noticed that the damage process is a very complex one and the other previously mentioned causes of damage might have contributed to these noticed cracks as well.

The lack of maintenance due to the limited budget allocated for the restoration works by the Ministry of Antiquities has also an effect not only on Hosh al-Basha but also generally on the architectural heritage of Egypt [32]-[38]. Other causes like previous earthquakes and anthropogenic actions have contributed to the damage.

One clear example of the effect of the lack of maintenance on the tombs is shown in Figure 30. As can be noticed, the marble sides composing the "tarkee$b a h$ " were separated from each other and the tombstone collapsed (Figure 30(a) 
and Figure 30(b)) and the inside infill also was exposed. For the restoration, the infill was re-turned and confined again by the marble sides and the tombstone was returned to its place (Figure 30(c) and Figure 30(d)).

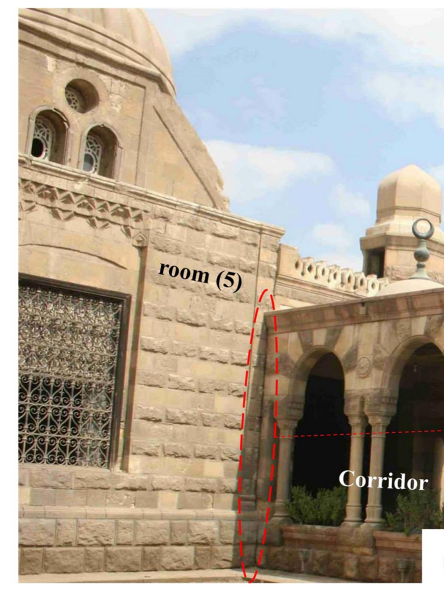

(a)
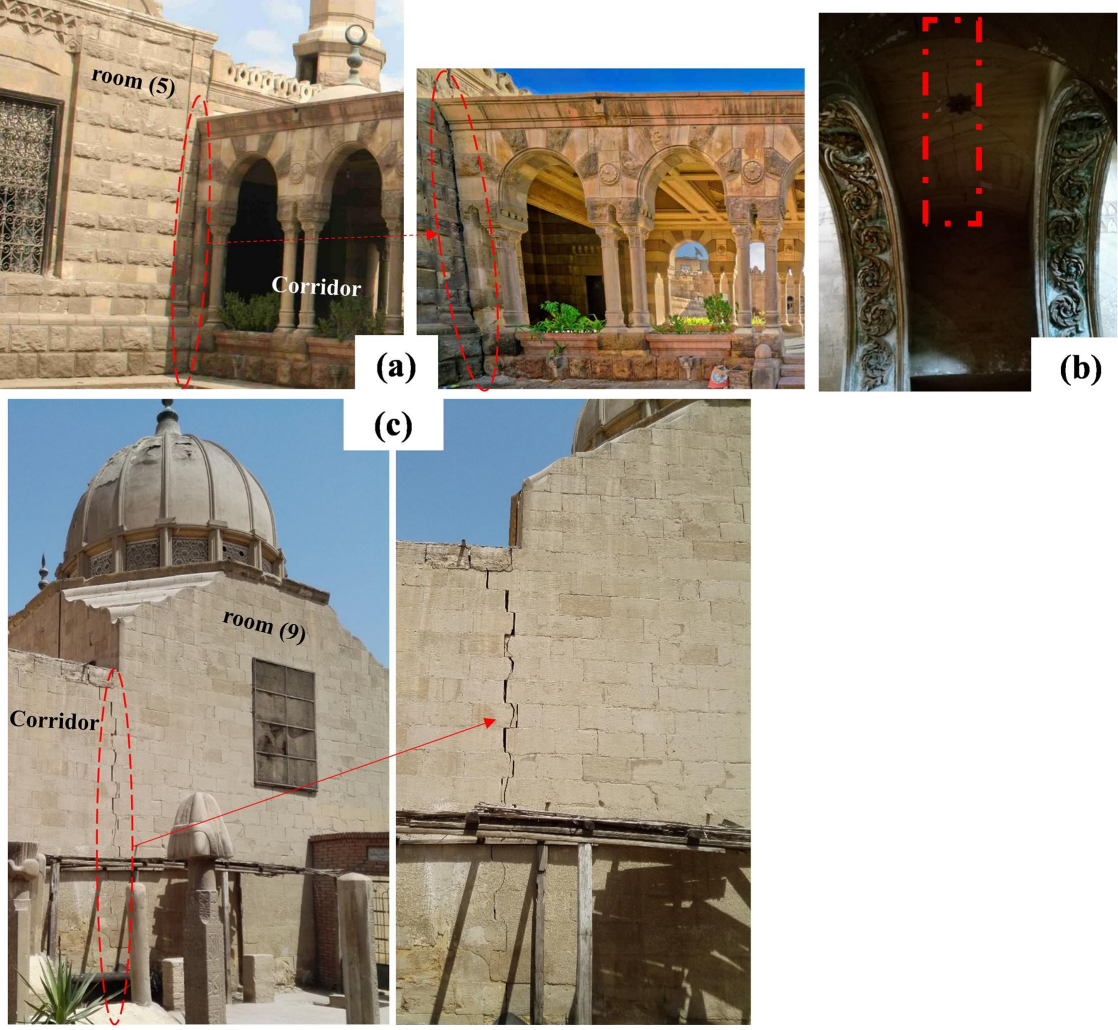

(b)

Figure 29. Examples of the noticed separation cracks due to the history of construction: (a) separation crack between the corridor and the room (5) wall, (b) separation crack in the vault between the rooms (3) and (4), (c) seperation crack between the corridor and the room (9). (explanations by the authors).
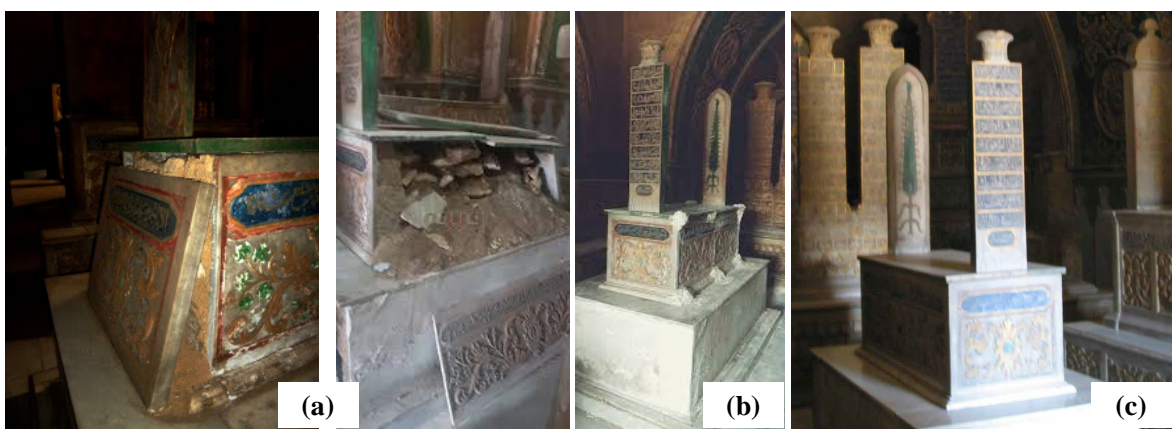

Figure 30. The tombstone number (7) in the room (6): (a) seperation of the marble side and collapse of the tombstone, (b) during restoration, (c) current state. (explanations by the authors). 


\section{Examination of the Construction Materials}

Samples were collected from various building materials of Hosh El-Basha including the limestone, the marble, the mortar between the limestone blocks, the pigments, and the deterioration products. All the samples were taken from cracked or detached areas. The purpose was to characterize the construction materials and to understand better the causes of damage.

\subsection{Microscopy Investigation}

The samples were mounted in a transparent epoxy rersin support and polished for cross-sectional analysis. Observation and photography of the stratigraphy were performed using a Zeiss Axio Can MRC5 Stereoscopic microscope with Discovery V.20 camera. Based on the characteristics of each sample, the samples were observed under various magnifications, from $20 \times$ to $50 \times$. The petrography study was carried out using Olympus BX51 TF Japan attached with a digital camera under magnification 20x up to 40x.

The examination of thin sections of the limestone samples under plane polarized light microscope (PLM) displayed fine-grained calcite crystals, on top of iron oxides, clay minerals, and numerous grains of quartz that were also found occurring as subrounded to angular. The study showed fossils fragments as shown in Figure 31.

The examination of thin sections of the marble samples under PLM revealed that all marble samples are carbonate rocks consisting of both calcite and dolomite in rather variable proportions, with significant to moderate contents of quartz and orthoclase, Figure 32(a). Most of the calcite crystals were granoblastic, with equidimensional shapes (pseudo-hexagonal) and different sizes, Figure 32(b) \& Figure 32(c). The presence of the distinctive mosaic texture of marble is illustrated in Figures 32(c)-(e). Marble is characterized by the sugar-crossed texture of the mineral granules of the calcite as a result of the transformation processes and the presence of the separation lines characteristic of the calcite the main component of the marble, Figure 32(f).

The microscopic examination of the cross-section of the painted marble revealed that the artist carried out the pigments directly on the marble decorations as traces of the blue, red, and brown pigments were found (Figure 33(a) \& Figure 33(b)). The examination also showed that marble support is full of holes resulting from the carbonization process (Figure 33(c) \& Figure 33(d)).

\subsection{XRD Analysis}

Mineral compositions of the samples were inducted by X-Ray Diffraction (XRD) patterns, using a Philips X-ray PW 1840 diffractometer. The patterns were run with Ni-filtered, $\mathrm{Cu} \mathrm{Ka}$ radiation $(\lambda=1.54056 \AA)$ at $30 \mathrm{kV}$ and $10 \mathrm{~mA}$, and a scan speed of $2^{\circ}(2 \theta) / \mathrm{min}$.

The XRD pattern of the limestone sample is given in Figure 34(a) showed 
that the sample consisted essentially of Calcite $\left(\mathrm{CaCO}_{3}\right)$. The XRD pattern of the salt sample taken from the limestone surfaces or between the blocks (Figure 34(b)) found to be consisted of Calcite (39.8\%), Halite $(\mathrm{NaCl})(45 \%)$, and Sylvite $(\mathrm{KCl})(15.2 \%)$. This result could be interpreted that the chlorides salts are the basic reason for stone deterioration at Hosh al-Basha and the salts are due to the groundwater salinity resulted from Ain Al-Sira and Khayalat Al-Shorta lakes as mentioned in section (3) above.

According to this analysis, the mortar consisted mainly of Gypsum (Ca$\left.\mathrm{SO}_{4} \cdot 2 \mathrm{H}_{2} \mathrm{O}\right)(77.4 \%)$, Calcite (17.2\%), Quartz $\left(\mathrm{SiO}_{2}\right)(1.8 \%)$, and Halite (3.6\%) was found due to salt penetration (Figure $34(\mathrm{c})$ ). The Calcite originated from the limestone powder, the Quartz was the filling material and the Halite found due to salts' presence in the mortar. The sample taken from the plaster found to be mainly from Gypsum (37\%), Zincite ( $\mathrm{ZnO})$ (28.4\%), Calcite (19.3\%), Halite (8.8\%), and Quartz (6.5\%) (Figure 34(d)). The Calcite was from the limestone powder, the Quartz was the filling material, the Zincite was from Zinc and the Halite was due to the salt presence.
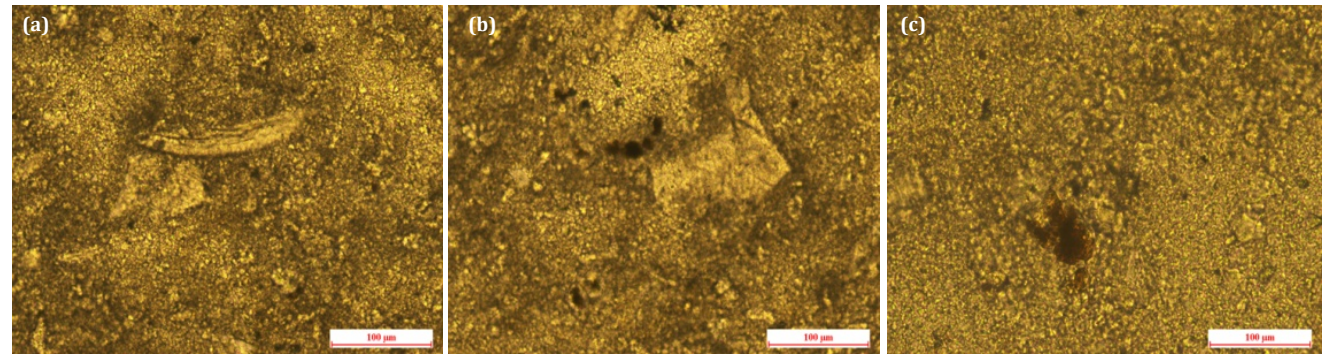

Figure 31. Optical micrographs: (a) fine grained calcite (micrite) and fossil fragments, (b) quartz grains as sub-rounded to angular, (c) iron oxides.
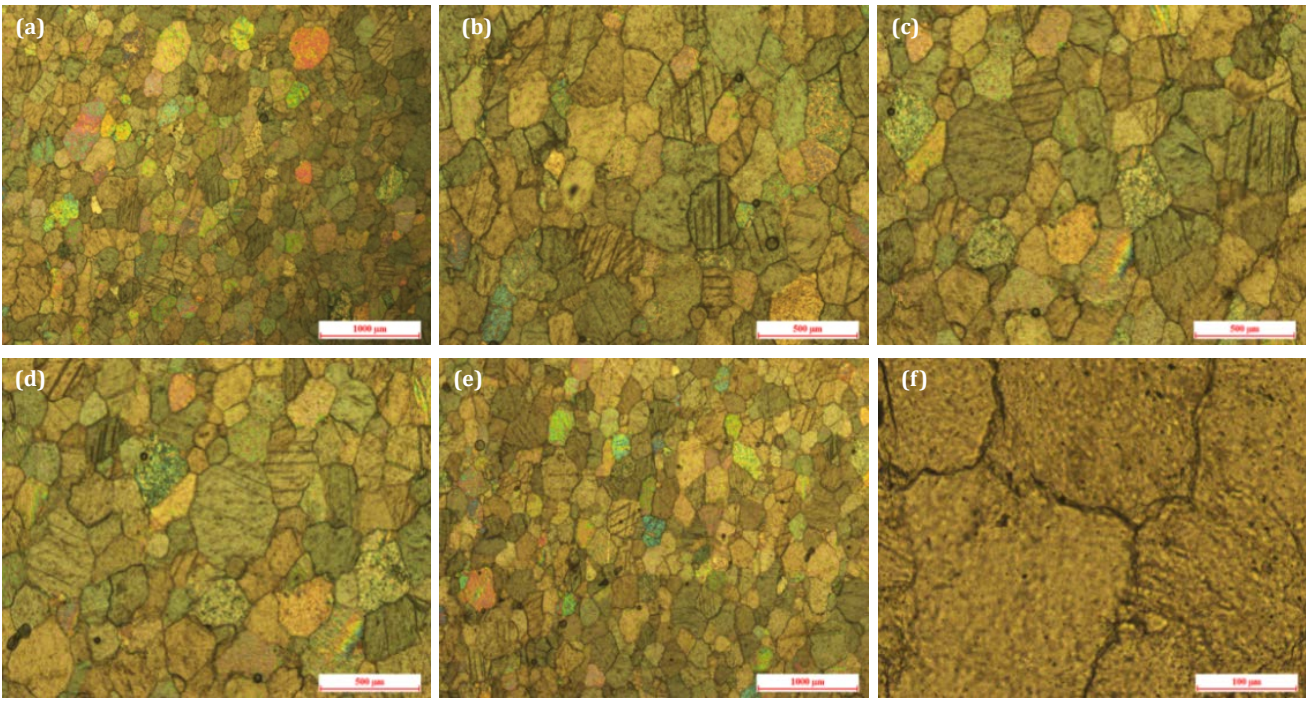

Figure 32. Petrography study of marble: (a) carbonate rocks consisting of both calcite, dolomite, quartz and orthoclase, (b) crystals were granoblastic with equidimensional shapes, (c), (d) and (e) distinctive mosaic texture of marble, (f) presence of the separation lines characteristic of the calcite. 

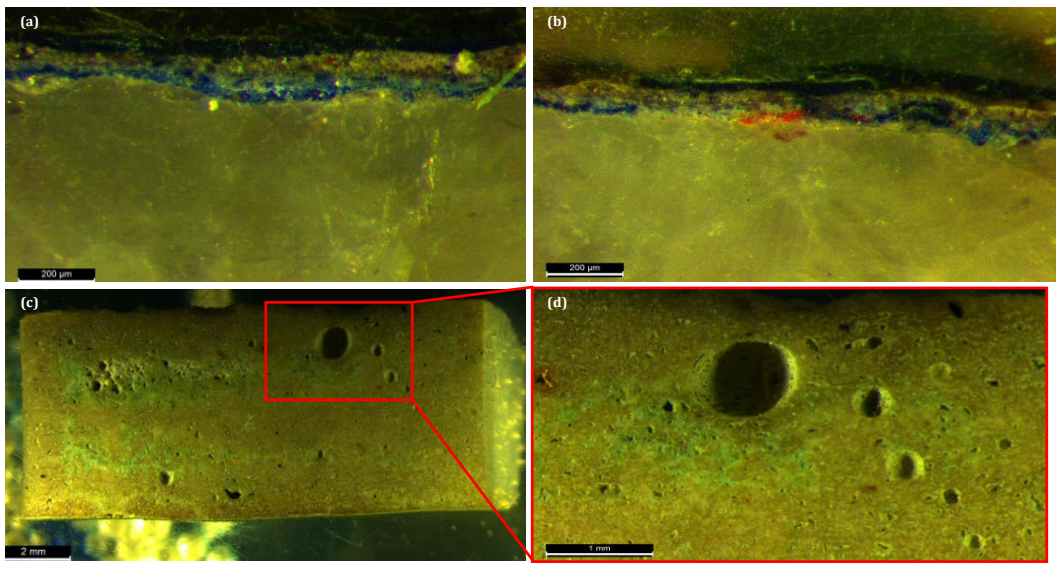

Figure 33. Cross-section of the painted marble: (a) \& (b) Stereomicroscope image of pigment at marble, (c) \& (d) holes at marble.
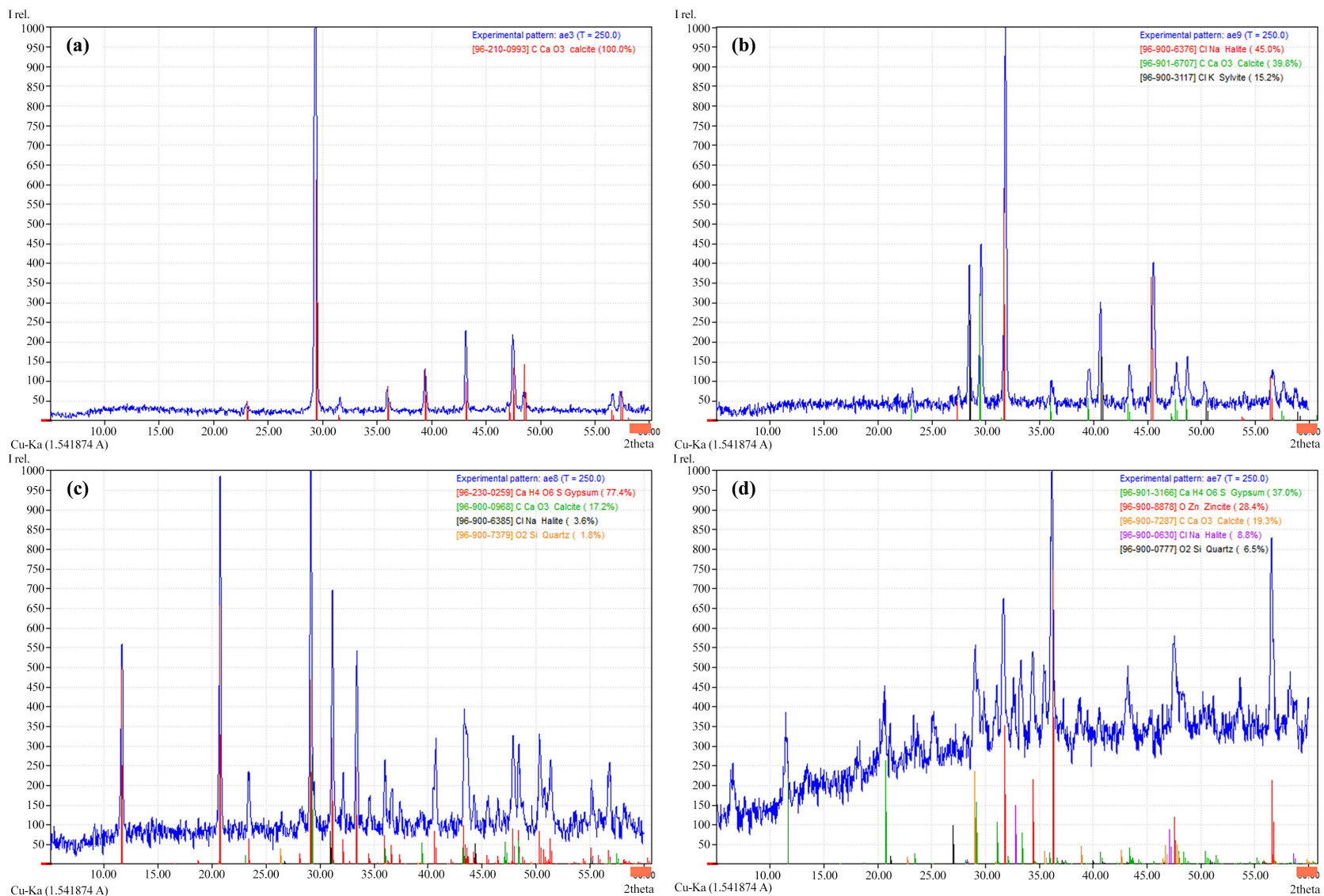

Figure 34. XRD patterns: (a) weathered limestone, (b) salt, (d) mortar, (e) plaster.

The XRD pattern of the deteriorated marble (Figure 35(a)) showed that the sample consisted of Calcite (35.6\%), Sylvite (73.3\%), and Halite (27.1). The XRD pattern of the mortar taken from between the marble slabs (Figure 35(b)) consisted essentially of Gypsum (61.2\%), Calcite (28.8\%), and Quartz (10\%). Accordingly, it is understood that the marble mortar consisted of mixing Gypsum as a major, lime, and a small amount of sand. 


\subsection{SEM-EDX Analysis}

A Scanning electron microscopy (SEM) used to observe the rocks forming minerals, weathered minerals, details of morphological features of the surface particles, voids, and its weathering status. The SEM was a JEOL JSM 6400 coupled with an Energy Dispersive X-ray spectrometer (EDX) was used to determine the chemical composition of the building materials.

The EDX microanalysis of the marble sample showed an almost pure carbonate composition with low amounts of Magnesium (Mg), Silica (Si), and alumina (Al), Figure 36(a) and Table 1. The distinguishing geochemical feature may be related to the different mineralogical compositions and the genetic environment of the materials.

The EDX pattern of the marble had some amounts of Sulfide and Chloride (S and $\mathrm{Cl}$ ) caused by weathering effects. The SEM results confirmed that the marble deterioration was due to the abundance of soluble salts. The SEM micrographs exhibited several alterations, such as cracks and pores (Figure 37(a)). Halite was identified as large prismatic grains (Figure 37(b)) and there were losses of cohesion between grains (Figure 37(c)). The SEM photomicrographs showed disintegration between the Calcite crystals and micro exfoliation (Figure 37(d)).

The EDX microanalysis of the plaster sample (Figure 36(b) and Table 1) showed that $\mathrm{Zn}$, Ca were the major elements in the sample. Considerable amounts of $\mathrm{S}, \mathrm{Na}$, and $\mathrm{Cl}$ were also recorded due to salt presence. The EDX analysis of the mortar sample confirmed the XRD result. The EDX microanalysis (Figure 36(c) and Table 1) showed that $\mathrm{Ca}$ and $\mathrm{Si}$ were the major elements in the sample. Considerable amounts of $\mathrm{Na}$ and $\mathrm{Cl}$ were also recorded due to salt presence.

Table 1. Results (Wt\%) of the EDX analysis.

\begin{tabular}{|c|c|c|c|c|c|c|c|c|c|c|c|}
\hline \multirow{2}{*}{ Analyzed Sample } & \multicolumn{11}{|c|}{ Elements } \\
\hline & $\mathrm{C}$ & $\mathrm{O}$ & $\mathrm{Na}$ & $\mathrm{Mg}$ & $\mathrm{Al}$ & $\mathrm{Si}$ & $S$ & $\mathrm{Cl}$ & $\mathrm{Ca}$ & $\mathrm{Zn}$ & MoL \\
\hline Marble & 8.79 & 50.59 & 2.42 & 0.84 & 0.93 & 3.25 & 10.92 & 3.30 & 18.98 & 0.0 & 0.0 \\
\hline Plaster & 21.27 & 37.80 & 0.01 & 1.48 & 0.66 & 1.28 & 7.64 & 4.41 & 5.35 & 20.11 & 0.0 \\
\hline Mortar & 26.97 & 40.55 & 5.31 & 0.0 & 2.52 & 5.43 & 0.0 & 2.42 & 11.45 & 0.0 & 5.35 \\
\hline
\end{tabular}
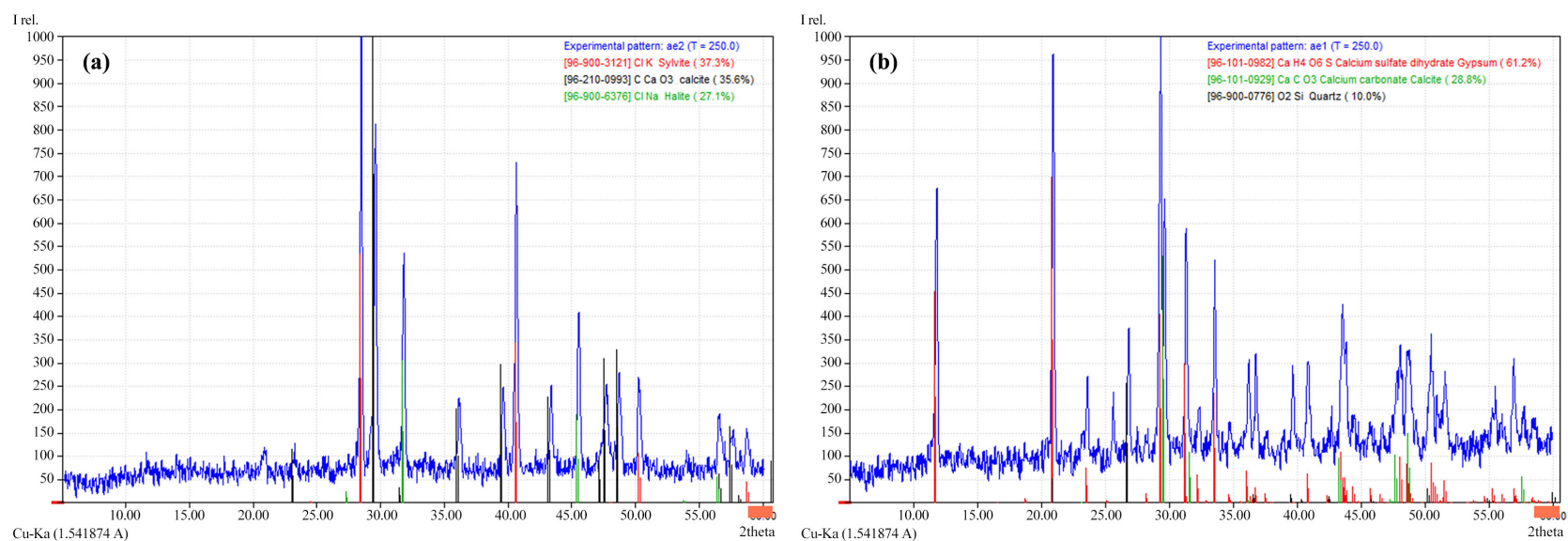

Figure 35. XRD patterns: (a) deteriorated marble, (b) marble slabs mortar. 


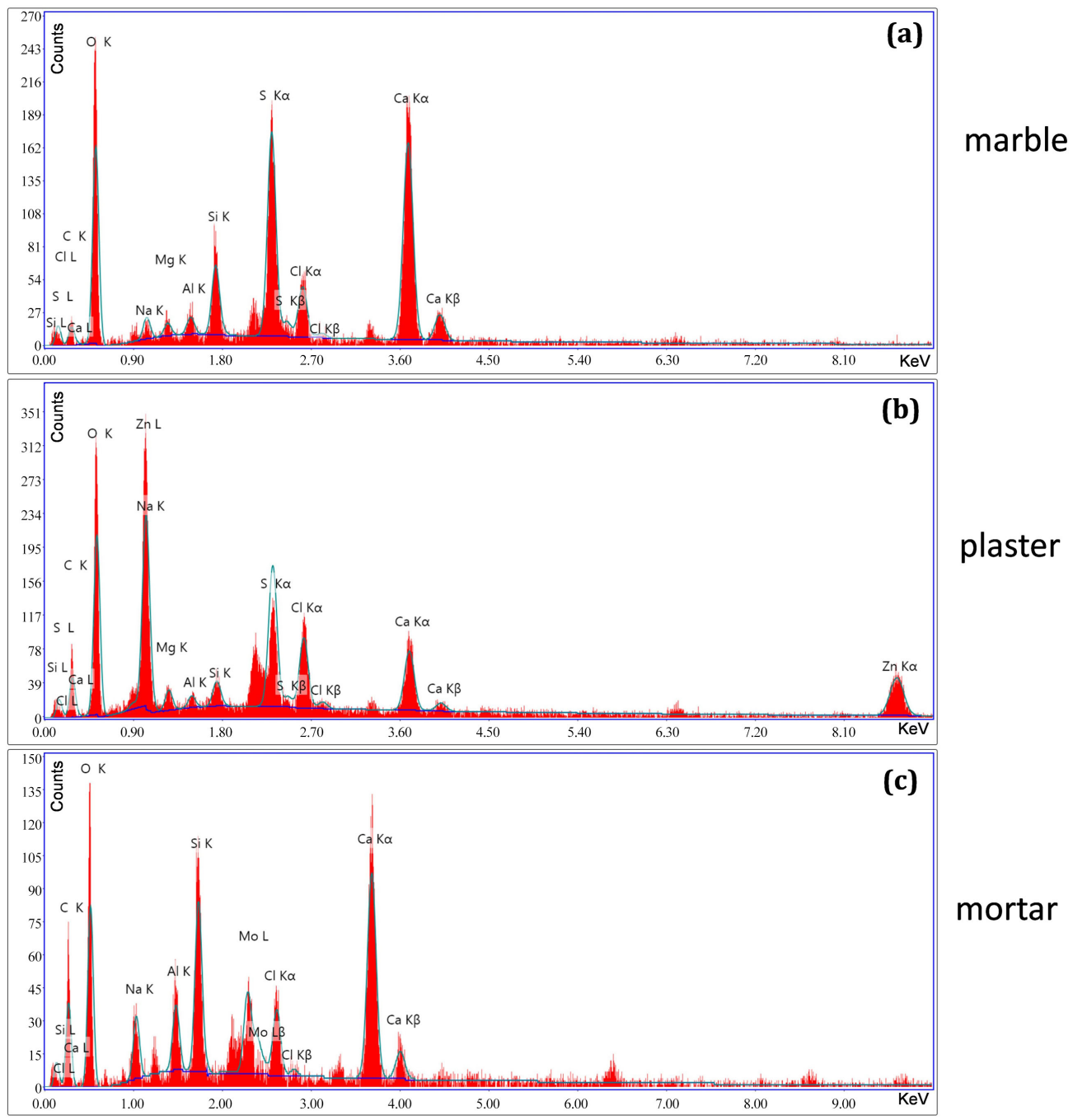

Figure 36. EDX patterns: (a) marble, (b) limestone plaster, (c) mortar samples between limestone blocks.

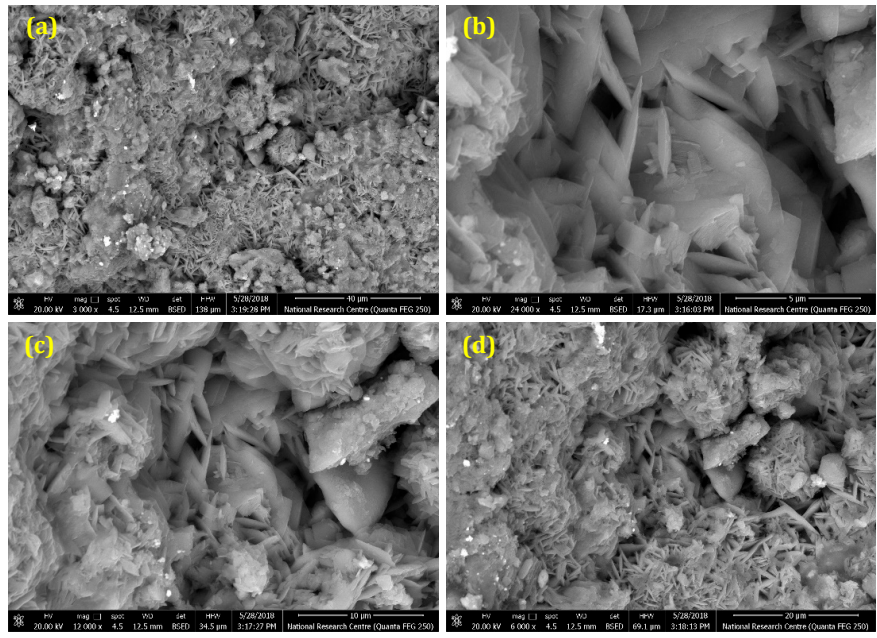

Figure 37. SEM micrograph of the marble: (a) cracks and pores, (b) prismatic grains of Halite, (c) losses of cohesion between grains, (d) disintegration between calcite crystals. 


\section{Conclusions}

This research investigated the damage manifested by the cemetery of the Royal Family and the characterization of its construction materials. The cemetery is very rich with decorative marble elements and is considered one of the masterpieces of Historic Cairo (listed since 1979 as a UNESCO World Heritage Site). The Royal Family ruled Egypt for about one and a half century from 1805 to 1952; therefore, the cemetery has a high historic value as 74 of the Royal Family were buried there.

The detailed historical research, literature review, visual inspection and photographical documentation allowed a good understanding of the manifested damage. It was found that all the structural elements including the domes, the squinches, the arches, and the walls are cracked. This could be attributed to several factors including the construction history of the cemetery, the groundwater's level variations, the lack of maintenance and the previous earthquakes.

The cemetery was constructed on six stages starting from the beginning of the 19th until the mid of the 20th century. This in turn resulted in relatively weak connections between its walls. In addition, it gave the possibility of having changes in the quality of the used construction materials and the foundations parameters (the depth, the dimensions, the types, and the materials). In addition, the groundwater continuous rising affected very badly the foundation soil. Historic Cairo, generally, was built over non-homogenous fill. This fill has unpredicted behavior when exposed to groundwater's variations that results in differential settlements of the foundations and consequently the diagonal cracks appeared in the structural elements.

The location of Hosh al-Basha near to two lakes characterized by its saline water played an important role in the manifested damage by salt effloresce and crystallization in the stone masonry elements and the decorated marble. The saline groundwater penetrated in the walls by capillarity and then evaporated leaving the salts inside to crystallize resulting in internal stresses in stones that were cracked and distorted.

The microscopy study revealed the following:

- The limestone had fine-grained calcite crystals, on top of iron oxides, clay minerals, and numerous grains of quartz were found occurring as subrounded to angular.

- The marble samples were carbonate rocks consisting of both calcite and dolomite in rather variable proportions, with significant to moderate contents of quartz and orthoclase.

- The artist carried out the pigments directly on the marble decorations as traces of the blue, red, and brown pigments were found. The marble support was full of holes resulting from the carbonization process.

The XRD analysis revealed the following:

- The salts were found to be Halite $(\mathrm{NaCl})$ and Sylvite $(\mathrm{KCl})$. Meaning that the chlorides salts were the basic reason for the stone and the marble deteriora- 
tion. The salts were due to the groundwater salinity resulted from Ain Al-Sira and Khayalat Al-Shorta lakes. These results matched with previous chemical analysis of the saline water of the aforementioned two lakes.

- The mortar consisted mainly of Gypsum, Calcite, and Quartz.

- The plaster found to be mainly from Gypsum, Zincite, Calcite, and Quartz. The SEM-EDX Analysis revealed the following:

- The marble was an almost pure carbonate composition with low amounts of Magnesium, Silica, and alumina. It suffered from several alterations, such as cracks and pores, disintegration between the Calcite crystals and micro exfoliation. It had some amounts of Sulfide and Chloride caused by weathering effects. These results confirmed that the marble deterioration was due to the abundance of soluble salts.

- The plaster was found to be composed of $\mathrm{Zn}$ and Ca. Considerable amounts of $\mathrm{S}, \mathrm{Na}$, and $\mathrm{Cl}$ were recorded due to salt presence.

- $\mathrm{Ca}$ and $\mathrm{Si}$ were the major elements in the mortar. Considerable amounts of $\mathrm{Na}$ and $\mathrm{Cl}$ were also recorded due to salt presence.

The cemetery of the Royal Family is in need of an urgent conservation project to stop the on-going overall damage mechanisms due to the effect of the groundwater table rise and subsequent differential settlement. A detailed investigation is needed for the foundation soil of the cemetery by conventional bore-holes and modern means like Ground Penetrating Radar (GPR) and Multichannel Analysis of Surface Waves (MASW) to reveal its properties and characteristics. Monitoring of the observed wide cracks in the different structural elements is also needed to understand its evolution in time.

\section{Conflicts of Interest}

The authors declare no conflicts of interest regarding the publication of this paper.

\section{References}

[1] Antoniou, J., Bianca, S., El-Hakim, S., Lewcock, R. and Welbank, M. (1985) The Conservation of the Old City of Cairo. In: Evin, A., Ed., The Expanding Metropolis. Coping with the Urban Growth of Cairo, Concept Media/Aga Khan Award for Architecture, Singapore, 64-90.

[2] Atalla, M. (1997) Ground Water Investigation at Tri-Religion Monumental Region of Old Cairo. International Symposium on Engineering Geology and the Environment, Athens, June 1997, 3053-3056.

[3] Hassan, N.A., Kotb, A., Hassan, A.A. and Hagras, M.A. (2012) Dewatering Using Groundwater Modelling in Al-Fustat Area, Old Cairo, Egypt. Ain Shams Engineering Journal, 3, 349-358. https://doi.org/10.1016/j.asej.2012.04.010

[4] Elyamani, A. and Amer, S.M. (2017) Typical Reasons of the Degradation of Islamic Historical Structures and Its Surroundings and Proposals for Intervention: The Case of Queen Safiyya Mosque in Cairo. Annual of the General Union of Arab Archaeologists, 20, 1572-1605. https://doi.org/10.21608/cguaa.2017.29853 
[5] Elyamani, A., Soliman, A., Osama, W., Yehya, H. and Ashraf, N. (2020) Monumental Buildings under Harsh Surrounding Conditions: The Case Study of Fatima Khatun Mausoleum in Historic Cairo. Special Issue of the Journal Al Malweah for Archaeological and Historical Studies, 197-226.

[6] El-Habashi, A. and Ahmed, E.S. (2019) Groundwater Management for the Enhancement of the Urban Fabric in Historic Cairo. Engineering Research Journal, 42, 159-169. https://doi.org/10.21608/erjm.2019.66280

[7] Shahin, M.M. (1990) Impacts of Urbanization of the Greater Cairo Area on the Groundwater in the Underlying Aquifer. IAHS Publication, International Association of Hydrological Sciences, Wallingford, 243-249.

[8] El Arabi, N.E. (1999) Problems of Groundwater Quality Related to the Urban Environment in Greater Cairo. IAHS-AISH Publication, Wallingford, 29-37.

[9] El-Sayed, S.A. (2018) Study of Groundwater in Northeast Cairo Area, Egypt. Journal of Geoscience and Environment Protection, 6, 229-251. https://doi.org/10.4236/gep.2018.64014

[10] Hassan, H.M., Fasan, M., Sayed, M.A., Romanelli, F., El-Gabry, M.N., Vaccari, F. and Hamed, A. (2020) Site-Specific Ground Motion Modeling for a Historical Cairo Site as a Step towards Computation of Seismic Input at Cultural Heritage Sites. Engineering Geology, 268, Article ID: 105524.

https://doi.org/10.1016/j.enggeo.2020.105524

[11] Antoniou, A., Lekkas, E. and Chiotinis, N. (2015) Preservation of Saint George's Church at Cairo, Egypt. In: Lollino, G., Giordan, D., Marunteanu, C., Christaras, B., Yoshinori, I. and Mar-gottini, C., Eds., Engineering Geology for Society and Territory, Vol. 8. Springer, Cham, 95-98. https://doi.org/10.1007/978-3-319-09408-3_13

[12] Poscolieri, M., Parcharidis, I., Foumelis, M. and Rafanelli, C. (2011) Ground Deformation Monitoring in the Greater Cairo Metropolitan Region (Egypt) by SAR Interferometry. Journal of Environmental Semeiotics, 4, 17-45. https://doi.org/10.3383/es.4.3.1

[13] URHC (2012) Urban Regeneration Project for Historic Cairo. First Report of Activities, July 2010-June 2012. http://urhcproject.org

[14] El-Sohby, M.A. and Mazen, S.O. (1988) Geotechnical Characterization of Subsoil Deposits at Cairo. Proceedings. Second International Conference on Case Histories in Geotechnical Engineering, St. Louis, 1-5 June 1988, Paper No. 256.

[15] Google Maps. https://www.google.com/maps

[16] Abed, M.M.A. (1998) The Cemetery of the Royal Family in Imam al-Shafi'i: Architectural Decorative Study. MA Dissertation, South Valley University, Qena.

[17] The Center of Documenting Monuments of the Egyptian Ministry of Antiquities.

[18] Photographical Documentation of Hosh al-Basha by the Firm of "Dewan al-E'mara we al-Turath".

[19] Williams, C. (2008) Islamic Monuments in Cairo: The Practical Guide. American University in Cairo Press, Cairo.

[20] Photo by Ahmed Mansour. https://www.facebook.com/photo?fbid=10164136031815397\&set=a.1015177039338 0397

[21] Sketch by the English Naturalist James Sowerby. https://www.periodpaper.com/collections/other-art/products/1871-wood-engraving -tomb-headstone-grave-cairo-cemetery-tarkeebeh-marble-egypt-160421-xgqb7-042 
[22] Kamel, A.M. (2004) How to Adapt with Environmental Effect on Ain El-Sira Spring, El-Imam El-Shaffie Pools and Hazards. Bulletin of Geography and Cartography Studies Center, Menoufia University, Vol. 6.

[23] Elyamani, A. (2015) Integrated Monitoring and Structural Analysis Strategies for the Study of Large Historical Construction. Application to Mallorca Cathedral. Ph.D. Dissertation, Technical University of Catalonia, Barcelona.

[24] Elyamani, A. and Roca, P. (2018) One Century of Studies for the Preservation of One of the Largest Cathedrals Worldwide: A Review. Scientific Culture, 4, 1-24.

[25] Caselles, O., Clapes, J., Elyamani, A., Lana, J., Segui, C., Martin, A. and Roca, P. (2018) Damage Detection Using Principal Component Analysis Applied to Temporal Variation of Natural Frequencies. 16th European Conference on Earthquake Engineering, Thessaloniki, 18-21 June 2018, 1-12.

[26] Caselles, O., Clapes, J., Roca, P. and Elyamani, A. (2012) Approach to Seismic Behavior of Mallorca Cathedral. 15th World Conference of Earthquake Engineering, Lisbon, 24-28 September 2012, 11636-11645.

[27] Elyamani, A., Caselles, O., Clapes, J. and Roca, P. (2012) Assessment of Dynamic Behavior of Mallorca Cathedral. 8th International Conference of Structural Analysis of Historical Construction, Wroclaw, 15-17 October 2012, 2376-2384.

[28] Elyamani, A., Roca, P., Caselles, O. and Clapes, J. (2017) Seismic Safety Assessment of Historical Structures Using Updated Numerical Models: The Case of Mallorca Cathedral in Spain. Engineering Failure Analysis, 74, 54-79.

https://doi.org/10.1016/j.engfailanal.2016.12.017

[29] Elyamani, A., Caselles, O., Roca, P. and Clapes, J. (2017) Dynamic Investigation of a Large Historical Cathedral. Structural Control and Health Monitoring, 24, e1885. https://doi.org/10.1002/stc. 1885

[30] Elyamani, A., Caselles O., Roca, P. and Clapes, J. (2018) Integrated Dynamic and Thermography Investigation of Mallorca Cathedral. Mediterranean Archaeology and Archaeometry, 18, 221-236.

[31] Elyamani, A., Roca, P., Caselles, O. and Clapes, J. (2019) Evaluation of Mallorca Cathedral Seismic Behavior Using Different Analysis Techniques. Mediterranean Archaeology and Archaeometry, 19, 41-60.

[32] Elyamani, A. (2018) Re-Use Proposals and Structural Analysis of Historical Palaces in Egypt: The Case of Baron Empain Palace in Cairo. Scientific Culture, 4, 53-73.

[33] Saad, D.A., Elyamani, A., Moddather, M.H. and Mourad, S. (2019) A Fund-Allocation Optimization Framework for Prioritizing Historic Structures' Conservation Projects -An Application to Historic Cairo. Proceedings of Canadian Society of Civil Engineers Annual Conference, Laval, 12-15 June 2019, CON46-1-CON46-10.

[34] El-Derby, A.A.O.D. and Elyamani, A. (2016) The Adobe Barrel Vaulted Structures in Ancient Egypt: A Study of Two Case Studies for Conservation Purposes. Mediterranean Archaeology and Archaeometry, 16, 295-315.

[35] Moustafa, S., Anwar, S., Ashraf, D., Ramadan, S. and Elyamani, A. (2015) The Tomb of the High Priest of Aton in the Regime of King Akhenaten: Description, Damage and Restoration Works. 4th International Conference of Faculty of Archaeology, Cairo University: Egypt and Mediterranean Countries through Ages, Cairo, 14-18 October 2015, 1-9.

[36] Elyamani, A., El-Rashidy, M.S., Abdel-Hafez, M. and Gad El-Rab, H. (2018) A Contribution to the Conservation of 20th Century Architectural Heritage in Khedival Cairo. International Journal of Conservation Science, 9, 55-70. 
[37] Adel, A., Mohamed, N., Abdel-Maksoud, N., Sobhy, M., Hossam-El-Din, D. and Elyamani, A. (2017) On the Conservation and Re-Use of Sednaoui El-Khazender Historical Building in Attaba. The First Arab Conference for Restoration and Reconstruction, Cairo, 9-11 October 2017, 1-27.

[38] Elyamani, A., Ali, N.M., Abdel-Maksoud, N. and Adel, A. (2019) A Study on the Surroundings of Sednaoui El-Khazendar Historical Building in Khedival Cairo and Proposals for Improvement and Development. International Journal of Heritage and Museum Studies, 1, 1-14. https://doi.org/10.21608/ijhms.2019.118687 